\title{
Physiology and pathophysiology of the vasopressin-regulated renal water reabsorption
}

\author{
Michelle Boone • Peter M. T. Deen
}

Received: 24 January 2008 /Revised: 13 March 2008 /Accepted: 16 March 2008 /Published online: 23 April 2008

(C) The Author(s) 2008

\begin{abstract}
To prevent dehydration, terrestrial animals and humans have developed a sensitive and versatile system to maintain their water homeostasis. In states of hypernatremia or hypovolemia, the antidiuretic hormone vasopressin (AVP) is released from the pituitary and binds its type-2 receptor in renal principal cells. This triggers an intracellular cAMP signaling cascade, which phosphorylates aquaporin-2 (AQP2) and targets the channel to the apical plasma membrane. Driven by an osmotic gradient, prourinary water then passes the membrane through AQP2 and leaves the cell on the basolateral side via AQP3 and AQP4 water channels. When water homeostasis is restored, AVP levels decline, and AQP2 is internalized from the plasma membrane, leaving the plasma membrane watertight again. The action of AVP is counterbalanced by several hormones like prostaglandin E2, bradykinin, dopamine, endothelin-1, acetylcholine, epidermal growth factor, and purines. Moreover, AQP2 is strongly involved in the pathophysiology of disorders characterized by renal concentrating defects, as well as conditions associated with severe water retention. This review focuses on our recent increase in understanding of the molecular mechanisms underlying AVP-regulated renal water transport in both health and disease.
\end{abstract}

Keywords Water reabsorption - Aquaporin-2.

PKA phosphorylation - Protein trafficking .

Nephrogenic diabetes insipidus · Polycystic kidney disease

\footnotetext{
M. Boone $\cdot$ P. M. T. Deen $(\triangle)$

Department of Physiology (286),

Nijmegen Centre for Molecular Life Sciences,

Radboud University Nijmegen Medical Centre,

P.O. Box 9101, 6500 HB Nijmegen, The Netherlands

e-mail: P.Deen@ncmls.ru.nl
}

\section{Introduction}

Maintaining water homeostasis by controlling both the osmolality and intravascular blood volume is essential for terrestrial mammals to survive. Water is lost through breathing, sweating, defecation, and urination and is obtained through glucose metabolism, drinking, and urinary water conservation. While several of these processes occur autonomic in healthy individuals, body water homeostasis is tightly controlled by regulating both water intake (drinking) and urinary water excretion. Changes in intravascular blood volume are sensed by vascular volume- and baroreceptors, which regulate the release of the antidiuretic hormone arginine vasopressin (AVP) [151]. Changes in osmolality are sensed by osmoreceptors located within specific regions of the hypothalamus, the organum vasculosum lamina terminalis (OVLT) and the subfornical organ (SFO) [21, 229]. In states of hypernatremia, these receptors are activated, which results in the sensation of thirst and subsequent water intake. Furthermore, neurons from the OVLT and SFO project to the supraoptic and paraventricular nuclei, where AVP is synthesized. These neurons project to the posterior pituitary from where AVP is released into the blood and sets out for the kidney where water excretion is governed (reviewed in [21, 115]). Approximately $90 \%$ of all water filtered by the glomeruli is reabsorbed constitutively in the proximal tubule and descending loop of Henle. Depending on the body's needs, remaining water can be reabsorbed in renal collecting duct, defining the final urine concentration. The adjustment of water reabsorption mainly depends on the release of AVP. When reaching the kidney, AVP binds its vasopressin V2 receptor (V2R) in the basolateral membrane of principal collecting duct cells, initiating a signal transduction cascade that consists of activation of adenylate cyclase (AC) via the 
stimulatory $\mathrm{G}(\mathrm{Gs})$ protein, an increase in intracellular cAMP levels, and activation of protein kinase A (PKA). Subsequently, aquaporin-2 (AQP2) water channels are phosphorylated and translocated from intracellular storage vesicles to the apical plasma membrane, rendering this membrane permeable to water $[55,162,163,228]$. Due to the increase in water permeability, water is able to pass the apical membrane passively through AQP2 along the osmotic $\mathrm{NaCl}$ and urea gradient and leaves through AQP3 and AQP4, which are constitutively expressed on the basolateral side of these cells. When isotonicity is restored, reduced blood AVP levels results in AQP2 internalization, leaving the apical membrane watertight again.

\section{Activation of AQP2 translocation}

Adenylate cyclase in the renal collecting duct

It is widely accepted that short-term AQP2 regulation, meaning AQP2 shuttling between intracellular storage vesicles and the apical plasma membrane, requires a functional AVP-AC-cAMP-PKA signaling cascade (Fig. 1). Upon V2R stimulation by AVP, membrane-bound AC is activated to synthesize cAMP from ATP. So far, nine mammalian AC isoforms have been identified. In the outer medullary collecting duct (OMCD), $\mathrm{Ca}^{2+}$-inhibitable isoforms AC5 and AC6 were detected by in situ hybridization [77]. AC6 was found in principal cells, whereas both AC5 and AC6 were detected in intercalated cells. In inner medullary collecting duct (IMCD), AC2-7 and AC9 mRNA were observed by RT-PCR [84]. So far, only $\mathrm{AC} 3, \mathrm{a} \mathrm{Ca}^{2+}$. stimulated isoform, and AC6 proteins have been detected in IMCD [84]. Their presence in principal cells suggests that one or both isoforms are responsible for the AVP-stimulated rise in cAMP. The contribution of each isoform to the cAMP increase, however, remains to be elucidated.

\section{Epac signaling}

Activation of $\mathrm{AC}$ increases intracellular cAMP levels. Traditionally, the role of intracellular cAMP in AQP2 translocation was thought to be restricted to the activation of PKA. Previously, a novel target of cAMP was discovered, namely "the exchange protein directly activated by cAMP" (Epac) 1 and 2 (also known as cAMP guaninenucleotide-exchange factor) [37]. Epac1 and Epac2 activate specifically Rap1 and Rap2, monomeric G proteins of the Ras family, which are implicated in cellular functions like cell adhesion and cell-junction formation (reviewed in [17]). In addition, Epac has been associated with exocytosis, mitogen-activated protein kinase (MAPK) signaling,

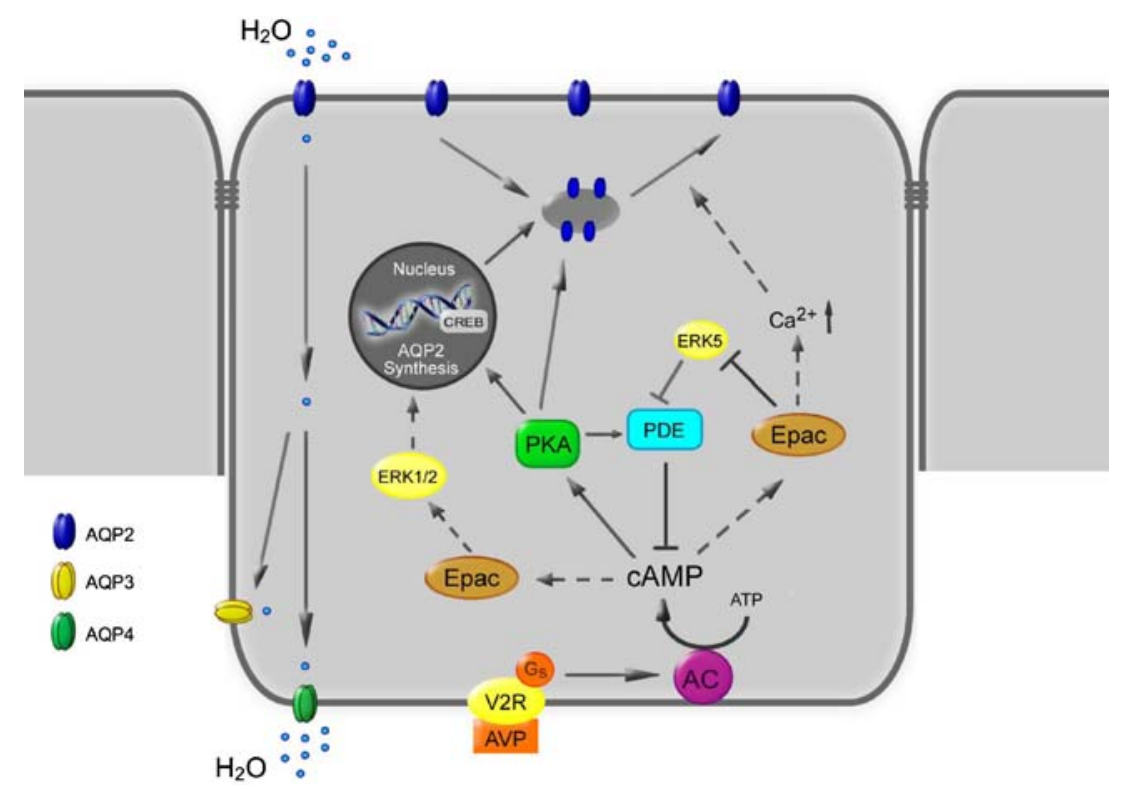

Fig. 1 Model of the regulation of water permeability in renal collecting duct cells. Binding of vasopressin $(A V P)$ to the V2 receptor $(V 2 R)$ in the basolateral membrane activates adenylate cyclase $(A C)$ and increases intracellular cAMP levels. This activates protein kinase $\mathrm{A}(P K A)$, which induces translocation of AQP2-bearing vesicles to the apical membrane, rendering this membrane water permeable. In addition, cAMP can activate exchange protein directly activated by cAMP (Epac). Epac can increase cytosolic $\mathrm{Ca}^{2+}$, which may facilitate
AQP2 translocation. cAMP signaling is abrogated by phosphodiesterase $(P D E)$-mediated degradation of cAMP. Epac might control PDE activity by inhibiting ERK5, which inhibits PDE. PKA also increases AQP2 synthesis by phosphorylation of the cAMP-responsive element-binding $(C R E B)$ protein and its binding to the $\mathrm{AQP} 2$ promoter. Possibly, Epac enhances AQP2 synthesis by inhibiting extracellular signal-regulated kinases 1 and 2. Water, entering the principal cell via AQP2, can leave the cell via constitutively expressed AQP3 and AQP4 
hormone gene expression, and phospholipase C-epsilon (PLC- $\varepsilon$ ) activation [17]. Recently, several studies demonstrated that Epac is also involved in the regulation of ion channel activity and, as such, Epac2 has been implicated in the release of $\mathrm{Ca}^{2+}$ from internal stores via ryanodinesensitive $\mathrm{Ca}^{2+}$-channels (see also further $[5,78,105,106]$ ). Both Epac1 and Epac2 are highly expressed in kidney and might therefore be of interest in the regulation of AQP2. Yip provided the first evidence for a role of Epac in AQP2 regulation by demonstrating that activation of Epac with a specific agonist induces intracellular $\mathrm{Ca}^{2+}$ mobilization as well as AQP2 translocation [248]. Possibly, both PKAmediated phosphorylation and Epac-activated $\mathrm{Ca}^{2+}$ mobilization play a role in AVP-activated AQP2 translocation towards the apical membrane. To which extent this novel pathway contributes to the AVP-induced water reabsorption remains to be established.

$\mathrm{Ca}^{2+}$ and AQP2-mediated water reabsorption

$\mathrm{Ca}^{2+}$ plays an important role in AQP2-regulated water reabsorption. While local increases in intracellular $\mathrm{Ca}^{2+}$ concentration are known to be of great importance for the fusion of vesicles with the plasma membrane (reviewed in $[10,71])$, the importance of a transient $\mathrm{Ca}^{2+}$ increase for AQP2 translocation is still controversial. AVP induces a transient increase in the intracellular $\mathrm{Ca}^{2+}$ concentration and sustained $\mathrm{Ca}^{2+}$ oscillations in microdissected rat $\mathrm{OMCD}$ and IMCD tubules $[29,43,136]$. In perfused IMCDs, preincubation with BAPTA, which buffers intracellular $\mathrm{Ca}^{2+}$, blocked the osmotic water permeability, indicating that intracellular $\mathrm{Ca}^{2+}$ is required for AQP2 membrane insertion $[31,247]$. In addition, both ryanodine-sensitive $\mathrm{Ca}^{2+}$ stores and calmodulin are likely to be involved in the $\mathrm{Ca}^{2+}$ dependent translocation of AQP2 since ryanodine and calmodulin blockers were shown to inhibit AVP-mediated AQP2 trafficking and water permeability in IMCD cells [31]. Lorenz et al., however, demonstrated that cAMP alone is sufficient to induce AQP2 shuttling, without the necessity of a cytosolic $\mathrm{Ca}^{2+}$ increase in IMCD cells [131]. Using Madin-Darby canine kidney (MDCK) cells stably transfected with AQP2 and stimulated with 1-desamino-8-Darginine vasopressin (dDAVP), we found similar results (unpublished data). Combined, these data suggest that intracellular $\mathrm{Ca}^{2+}$ but not necessarily an AVP-induced increase in $\mathrm{Ca}^{2+}$ is needed for AQP2 translocation.

Phosphodiesterase in the renal collecting duct

Phosphodiesterases (PDEs) play an important role in the control of cAMP levels within specific cellular compartments. After its cAMP-induced activation and subsequent phosphorylation of PKA target proteins like AQP2, PKA signaling is abrogated by PDE-mediated cAMP degradation. The activity of PDE can have profound physiological effects because increased PDE activity was found to cause hereditary nephrogenic diabetes insipidus (NDI) in mice $[88,95,209]$. Activated PKA directly phosphorylates and activates the PDE4D3 isoform, thereby confining its own activity $[28,201]$. Additionally, activated Epac1 is able to inhibit extracellular signal-regulated kinase 5 (ERK5), which inactivates PDE isotypes such as PDE3 and PDE4D3, thereby contributing to the control of cAMP signaling [40]. The PDE superfamily consists of 11 gene families, and several PDE transcripts are expressed along the nephron $[41,118,243]$. In the collecting duct, the $\mathrm{Ca}^{2+}$. and calmodulin-dependent PDE1 and the cGMP-specific PDE5 were identified, as well as the highly expressed cAMP-specific PDE4 [243].

During the last decade, it has become clear that intracellular cAMP levels are locally regulated in which the so-called kinase-anchoring proteins (AKAPs) play a crucial role. AKAPs bind PKA, PKA substrates, phosphatases, and PDEs, and due to their unique targeting domains, they target these proteins, and thus cAMP-induced signaling cascades to various subcellular compartments (reviewed in $[11,203])$. Indeed, in elegant studies, the Klussmann team identified AKAP18 $\delta$ as the important anchoring protein in AQP2 regulation in IMCD cells; because PDE4D was recruited by AKAP18 onto AQP2-bearing vesicles, AKAP18 8 and AQP2 were co-translocated to the apical membrane upon AVP stimulation, and the interaction between AKAP18 8 and PKA was abrogated by an increase in cAMP levels [79]. Moreover, using fluorescence resonance energy transfer on a PKA phosphorylation-sensitive probe, they showed in vivo IMCD cAMP dynamics to occur on AQP2-containing vesicles.

\section{The cGMP pathway}

Formerly, AQP2 translocation was thought to be the result of cAMP increase only. However, compounds increasing cGMP levels, like the hormone atrial natriuretic peptide (ANP), nitric oxide donors, nitric oxide synthase substrate, and cGMP phosphodiesterase inhibitors, also appear to stimulate AQP2 translocation to the plasma membrane [18, 19]. The exact pathway responsible for the cGMP-mediated AQP2 effect, however, is not clear yet as it is unknown whether the activated cGMP-mediated protein kinase $\mathrm{G}$ (PKG) directly phosphorylates $\mathrm{AQP} 2$ and induces its translocation or whether the effect could be due to PKGmediated PKA activation. Moreover, the physiological relevance of these findings remains unclear since the effects of an increase in cGMP (through ANP) in vivo are controversial. Some studies show that ANP inhibits AVPstimulated water permeability and sodium reabsorption, 
whereas others do not $[39,171,172,192,198]$. In addition, a recent study demonstrated that ANP infusion induces a transient diuresis in rats [231].

\section{Activation of AQP2 expression}

\section{Hypertonicity}

In addition to short-term AQP2 regulation, AVP also increases long-term AQP2 expression in collecting duct cells, mediated through a cAMP-responsive element in the AQP2 promoter [149, 246]. However, recent studies reported that hypertonicity also increases AQP2 expression independent of AVP by activating two other pathways individually capable of increasing AQP2 transcription [70, 107, 126]. First of all, hypertonicity activates the transcription factor tonicity-responsive enhancer binding protein (TonEBP) by increasing its nuclear targeting, transactivation, and transcription. Subsequent binding of TonEBP to the AQP2 promoter increases the transcription of AQP2 [70]. Accordingly, TonEBP/NFAT5-deficient mice showed decreased AQP2 expression [130]. Secondly, activation of the nuclear factor of activated T cells c (NFATc) pathway can increase AQP2 expression in the collecting duct [126]. A hypertonicity-induced $\mathrm{Ca}^{2+}$ increase activates the protein phosphatase calcineurin that dephosphorylates NFATc. Subsequently, NFATc translocates to the nucleus to bind the AQP2 promoter and increases AQP2 transcription. Although both pathways independently increase AQP2 expression, cross-talk between these pathways increases AQP2 expression even further.

\section{MAPK signaling}

Several studies also indicate a role for MAPK signaling in AQP2 transcription. The V2R is capable of both inhibiting and activating ERK 1 and 2 (ERK1/2) MAPK activity. In this context, inhibition of ERK $1 / 2$ activation by V2R appears to be mediated by $G \alpha$ s and activation of PKA, whereas activation of ERK1/2 by V2R was shown to be independent of G-protein coupling but involves the recruitment of $\beta$-arrestin [30]. Recently, the hormone insulin, which is known to play a role in renal water and sodium excretion, was shown to enhance AVP-induced AQP2 expression by increasing its mRNA levels [26, 167]. The effect of insulin on AVP-dependent AQP2 mRNA expression is mediated by both ERK1/2 and p38 MAP kinase activation [26]. Umenishi et al. demonstrated that inhibition of ERK blocked the AVP-induced AQP2 expression, whereas inhibitors of two other MAP kinases, p38 and JNK kinase, did not affect AQP2 expression, indicating a role for ERK in regulating AVP-mediated AQP2 expression
[223]. Interestingly, this ERK activation was induced by the Epac-specific activator, 8CPT-2Me-cAMP. Together, these results suggest that AVP might initiate an alternative cAMP-Epac-ERK signaling pathway that contributes to AQP2 expression.

\section{AVP-independent activation of AQP2-mediated water transport}

While AVP plays a key role in the activation of AQP2mediated water transport, there is emerging evidence for the existence of AVP-independent mechanisms, regulating both AQP2 trafficking and expression. Oxytocin has been demonstrated to induce AQP2 translocation, which could be prevented by blockage of the V2R, suggesting that oxytocin can activate AQP2-mediated water transport via V2R signaling [96]. It remains to be established, however, whether this also occurs at physiologically obtainable levels of oxytocin. Furthermore, in AVP-deficient Brattleboro rats, induction of hyperosmolality increased AQP2 expression and translocation, indicating the presence of an AVPindependent mechanism [124]. Possibly, the hormone secretin might be involved in this. Secretin is a hormone traditionally involved in regulating the $\mathrm{pH}$ of duodenum content by controlling gastric acid release and bicarbonate secretion. Recently, however, it was found that secretin receptor knockout mice demonstrate mild forms of polyuria and polydipsia, as well as reduced levels of AQP2 [33]. Also, in secretin receptor knockout mice, the effect of water deprivation on AQP2 translocation and expression was also clearly diminished. Moreover, in normal mice, secretin was able to induce AQP2 plasma membrane translocation, as well as AQP2 expression in inner medullary tubular cells. The exact way in which secretin changes AQP2 expression remains to be defined.

\section{Inhibition of AQP2-mediated water transport}

Upon withdrawal of AVP, AQP2 is internalized from the membrane into intracellular storage vesicles, decreasing water reabsorption in the collecting duct. In addition, several hormones have been reported to antagonize AVPmediated water transport in kidney (Fig. 2).

\section{Luminal AVP}

In addition to the V2R, which is expressed at the basolateral membrane of principal cells, several studies suggest the presence of the $\mathrm{V} 1 \mathrm{a}$ receptor $(\mathrm{V} 1 \mathrm{aR})$ in the apical membrane of the collecting duct, which, upon activation in the presence of basolateral AVP, reduce the 


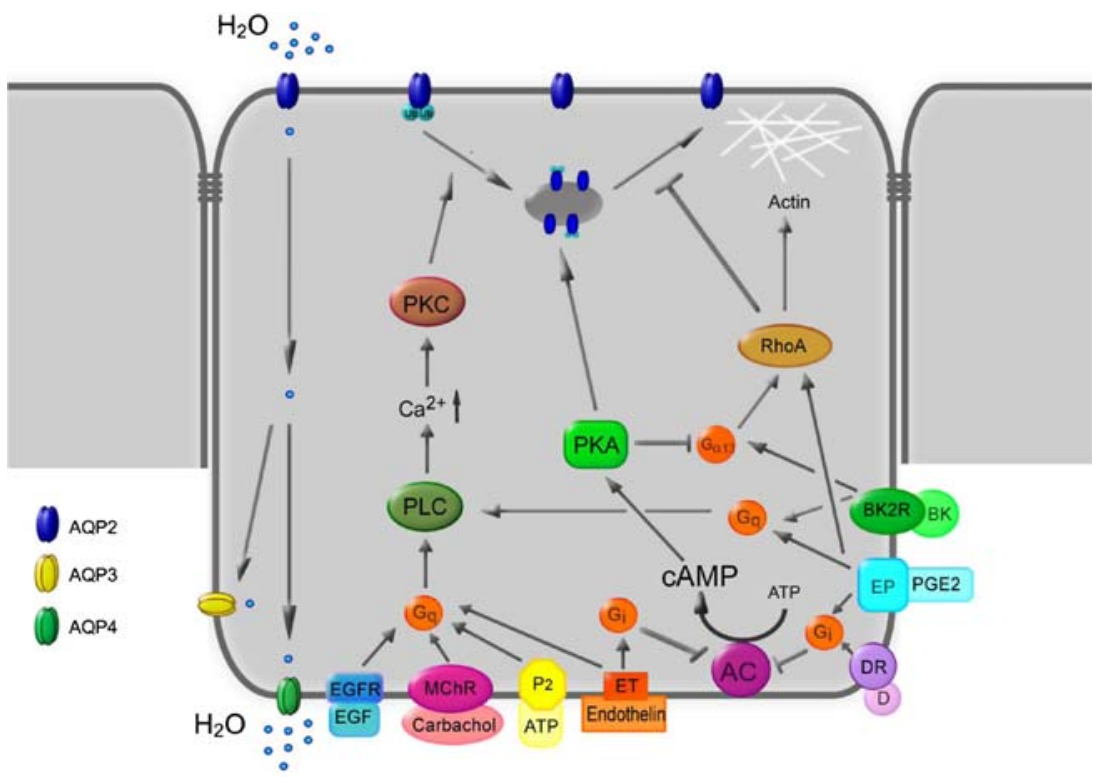

Fig. 2 Model of the inhibition of AQP2-mediated water reabsorption. Several hormones can antagonize AVP-induced water transport. Indicated are $A C$ adenylate cyclase, $A T P$ adenosine tri-phosphate, $B K(2 R)$ bradykinin (type-2 receptor), $c A M P$ cyclic adenosine monophosphate, $D(R)$ dopamine (receptor), $E G F(R)$ epidermal growth factor (receptor), $E P$ E-prostanoid receptor, $E T$ endothelin receptor,

V2R-mediated water reabsorption (reviewed in [170]). In the rabbit cortical collecting duct, luminal AVP was suggested to act via the V1R and to increase intracellular $\mathrm{Ca}^{2+}$ levels $[3,4,93]$. Others reported that $\mathrm{V} 1 \mathrm{aR}$ activation stimulated the synthesis of prostaglandins, which reduce AVP-induced cAMP accumulation (see below; [8]). V1aRmediated signaling might thus contribute to the inhibition of V2R-induced AQP2-mediated water reabsorption.

\section{Prostaglandin E2}

In the absence of AVP, prostaglandin E2 (PGE2) has been shown to stimulate water transport, but in its presence, PGE2 decreases water permeability [76]. The differences in PGE2-mediated actions on water permeability might be explained by the presence of four E-prostanoid receptor subtypes, denominated EP1, EP2, EP3, and EP4, and the different $G$ proteins they couple to (reviewed in [22]). The stimulatory effect of PGE2 on basal water permeability was reported to be most likely mediated via the EP4 receptor, which couples to Gs, thereby activating AC and increasing cAMP levels [193]. The inhibitory effect of PGE2 on AVPinduced water reabsorption is most likely mediated by EP1 and/or EP3 receptors [73, 76], as EP1 receptors couple to $\mathrm{G}_{q}$ and their activation by PGE2 increases intracellular $\mathrm{Ca}^{2+}$ levels, while the EP3 receptor couples to $\mathrm{G}_{i}$, thereby inhibiting cAMP generation. The molecular mechanism that underlies the PGE2-mediated inhibition of water transport, however, is far from complete understanding. PGE2 was
$G_{\alpha 13} \mathrm{G}$ protein involved in Rho family GTPase signaling, $G_{i}$ inhibitory $\mathrm{G}$ protein, $G_{q}$ PLC activating G protein, $M C h R$ muscarinic cholinergic receptor, $P 2$ purinergic receptor, $P G E 2$ prostaglandin-E2, $P K A$ protein kinase A, $P K C$ protein kinase $\mathrm{C}, P L C$ phospholipase $\mathrm{C}$, $U b$ ubiquitin. For details, see text

demonstrated to impair AVP- but not forskolin-induced water permeability, suggesting that PGE2 affects water permeability at a step between the V2R and AC [155]. In other studies, PGE2 was shown to inhibit AVP-induced water permeability by activating protein kinase $\mathrm{C}$ (PKC) without affecting cAMP levels $[74,157]$. A role for $\mathrm{Ca}^{2+}$ in mediating PGE2 action was also described [75]. In addition, PGE2 counteracts AVP action by retrieving AQP2 from the plasma membrane [161, 250].

Furthermore, modulation of the cytoskeleton by PGE2 is an important factor. Tamma et al. demonstrated that AVP inactivates the monomeric G protein Rho, which results in the depolymerization of the actin cytoskeleton and is a prerequisite for AQP2 translocation. Consistently, PGE2 binding to its EP3 receptor activates Rho, thereby inhibiting water permeability $[114,212,215]$. In line with an inhibitory function on AVP-induced water uptake, inhibition of PGE2 production by indomethacin increases urine osmolality in wild-type mice but not in EP3-deficient mice, suggesting that PGE2 indeed reduces AQP2 expression in the plasma membrane via the EP3 receptor [52]. Interestingly, however, in untreated EP3-deficient mice, urine volume and osmolality do not differ from wild-type mice, suggesting that PGE2 action through the EP3 receptor is not essential for the regulation of urinary concentrating mechanism under basal conditions [52]. Like EP3, EP1 is expressed along the collecting duct and could therefore also mediate the PGE2 effects on water transport. Indeed, in EP1-deficient mice, urine osmolality was diminished upon 
water deprivation compared to wild-type mice [110]. However, the defect in urine concentration could not be contributed to EP1 expression in collecting duct because the EP1-deficient mice demonstrated normal collecting duct AQP2 expression and translocation. Instead, it was concluded that the lack of the EP1 receptor affected the AVP production in the hypothalamus [110].

\section{Bradykinin}

Bradykinin also antagonizes AVP-induced water permeability. Indeed, in bradykinin receptor knockout mice, both water deprivation and administration of a V2R agonist results in more concentrated urine [2]. The intracellular action of bradykinin is diverse. At first, bradykinin can act indirectly by stimulating prostaglandin production [176]. Directly, bradykinin has been shown to activate the bradykinin-2 receptor (BK2R), which couples to $\mathrm{G}_{q}$ and activates PKC [180]. Furthermore, bradykinin, like PGE2, inhibits AQP2 translocation by activating Rho [211]. This effect is independent of PGE2 since bradykinin also inhibits Rho-dependent AQP2 translocation in the presence of indomethacin, which blocks cyclo-oxygenase production and thereby prostaglandin synthesis.

\section{Dopamine}

Dopamine also decreases water permeability in the collecting duct by lowering cAMP production. In the cortical collecting duct, this effect is mediated by dopamineinduced activation of D4-like receptors $[125,206]$. In the IMCD, the inhibitory effect of dopamine is mediated through $\alpha 2$-adrenoceptors, which can also be activated by catecholamines [46]. Like PGE2, dopamine also causes AQP2 internalization from the plasma membrane into intracellular storage vesicles independent of AQP2 dephosphorylation [161]. The mechanism, however, is unclear.

\section{Endothelin-1}

Collecting duct-derived endothelin-1 plays a key role in the regulation of systemic blood pressure and renal salt and water excretion (reviewed in [116]). Direct evidence for endothelin-1 functioning in renal water excretion originates from recent knockout studies. Collecting duct-specific endothelin-1 knockout mice showed reduced plasma AVP levels but normal plasma and urine osmolality, as well as urine volume [60]. An acute but not chronic water load was eliminated less efficient in the knockout mice compared to wild-type mice, and upon V2R agonist infusion, knockout mice demonstrated increased urine osmolality, AQP2 phosphorylation, and V2R expression [60]. Also, in these knockout mice, AVP-induced cAMP levels are increased, as well as AC5/6 protein levels [205]. Thus, collecting ductderived endothelin-1 appears to inhibit AVP-induced actions. Endothelin-1 is reported to have opposite effects on sodium and water excretion in different parts of the kidney, which is most likely due to the fact that endothelin-1 can exert its effects via two distinct receptor subtypes, $\mathrm{ET}_{\mathrm{A}}$ and $\mathrm{ET}_{\mathrm{B}}[56,57,81]$. Early studies suggested that endothelin-1 inhibits the AVP-induced water permeability in the renal collecting duct via activation of the $\mathrm{ET}_{\mathrm{B}}$ receptor through coupling to a $\mathrm{G}_{i}$ protein and inhibition of cAMP generation and through $\mathrm{G}_{q}$ protein coupling and activation of PKC $[47,156,173,217]$. This is thus in line with the data on the endothelin-1 knockout mice. However, collecting ductspecific $\mathrm{ET}_{\mathrm{B}}$ knockout mice showed no differences in water intake and urine volume during normal or high sodium diet compared to their control littermates [47, 60, 61, 66, 87]. Surprisingly, collecting duct-specific $\mathrm{ET}_{\mathrm{A}}$ knockout mice demonstrated higher AVP plasma levels, accompanied by a slightly increased ability to excrete acute water load [62]. Thus, signaling via the $\mathrm{ET}_{\mathrm{A}}$ receptor reduces endothelin-1 inhibition of AVP actions. Clearly, the exact mechanism responsible for the effects on AVP-mediated water reabsorption by the collecting duct-derived endothelin-1 remains elusive.

Acetylcholine and epidermal growth factor

Acetylcholine exerts its effects by activating the muscarinictype cholinergic receptors. Carbachol, an acetylcholine analogue, inhibits AVP-induced water flow but not cAMP production and mediates this effect by an increase in intracellular $\mathrm{Ca}^{2+}$ followed by PKC activation [67, 137]. Likewise, epidermal growth factor (EGF) inhibits AVP- and cAMP-stimulated water reabsorption through interaction with its EGF receptor, which also involves increased intracellular $\mathrm{Ca}^{2+}$ levels without affecting cAMP production $[23,67]$. The exact molecular mechanism remains to be determined.

\section{Extracellular purines}

It has already been known for a long time that the extracellular purines, ATP and UTP, decrease AVP-induced water permeability by increasing intracellular $\mathrm{Ca}^{2+}$ levels, which is accompanied by activation of PKC $[44,112]$. In addition, purines can also activate the Rho kinase pathway, which is involved in AQP2 trafficking, as described above [197, 212]. Extracellular purines can mediate their action via the ionotropic $\mathrm{P} 2 \mathrm{X}$ receptors $\left(\mathrm{P} 2 \mathrm{X}_{1-7}\right)$, as well as the metabotropic, G-protein-coupled P2Y receptors $\left(\mathrm{P}_{2} \mathrm{Y}_{1}, 2,4,6,11-13\right)$ [186]. Various P2X receptors have been identified in the collecting duct, including $\mathrm{P}_{2} \mathrm{X}_{3-6}$ receptors (reviewed in $[199,224])$. Clearest evidence for the involvement in AQP2 
regulation has been found for the $\mathrm{P}_{2} \mathrm{Y}_{2}$ receptor. In principal cells, both $\mathrm{P}_{2} \mathrm{Y}_{1}$ - and $\mathrm{P} 2 \mathrm{Y}_{2}$-like receptors are expressed in the basolateral membrane, and mRNAs of $\mathrm{P}_{2} \mathrm{Y}_{4}$ receptor, as well as $\mathrm{P}_{2} \mathrm{Y}_{6}$ receptor, were found along the OMCD (reviewed in [7, 199]). Furthermore, $\mathrm{P}_{2} \mathrm{Y}_{2}$ receptors were also localized to the apical membrane of collecting duct principal cells [7], although only basolateral ATP was shown to inhibit AVP-induced water permeability in perfused rat IMCD tubules [45]. Moreover, circulating AVP levels were shown to affect the expression of $\mathrm{P}_{2} \mathrm{Y}_{2}$ receptors since in water-deprived rats, decreased expression of $\mathrm{P}_{2} \mathrm{Y}_{2}$ receptors in IMCDs were found [113, 207]. Clearest evidence came from recent studies on $\mathrm{P}_{2} \mathrm{Y}_{2}$ receptor knockout mice. Although net urinary reabsorption was not different compared to wild-type mice, these knockout mice showed increased renal medullary expression of AQP2, as well as elevated urinary cAMP excretion. In response to the V2R antagonist SR121463, P2Y2 receptor knockout mice showed greater diuresis and lower urine osmolality compared to wild-type animals, suggesting that in the absence of $\mathrm{P} 2 \mathrm{Y} 2$ receptor, AVP enhances cAMP formation and AQP2mediated water reabsorption. This study provides the first evidence that under normal conditions, a continuous activation of the P2Y2 receptor by ATP exists, resulting in reduced cAMP formation and AVP-induced water reabsorption [187]. Whether other P2 receptors contribute to the purinergic effect on AVP-mediated water reabsorption remains elusive.

There are also indications that ATP may affect AQP2mediated water permeability indirectly. Hughes et al. showed that ATP also decreases the production of endothelin-1, thereby possibly affecting AVP-induced water transport through this hormone [90]. Moreover, extracellular purines stimulate $\mathrm{P}_{2} \mathrm{Y}_{2}$ receptor-mediated release of PGE2, which reduces water reabsorption as well [235].

\section{Extracellular $\mathrm{Ca}^{2+}$}

In addition to the hormones mentioned above, $\mathrm{Ca}^{2+}$ inhibits AVP-induced water transport by activation of the calcium receptor $(\mathrm{CaR})$. Although the importance of a transient increase in intracellular $\mathrm{Ca}^{2+}$ levels for AQP2 trafficking is still controversial, extracellular $\mathrm{Ca}^{2+}$ exerts clear effects on AVP-mediated water transport. $\mathrm{CaR}$ agonists have been shown to inhibit AVP-induced water permeability in perfused IMCD tubules [196]. In addition, extracellular $\mathrm{Ca}^{2+}$, acting through the $\mathrm{CaR}$, was shown to antagonize forskolin-induced AQP2 trafficking in AQP2-transfected collecting duct cells [181]. In vivo studies support these effects because in hypercalcemic rats, AVP was unable to increase the osmotic water permeability in the IMCD, and AQP2 protein levels were decreased [195]. Similarly, Valenti et al. found that while in healthy children with normally increased nighttime AVP levels daytime urinary
AQP2 levels were nearly half of the nighttime AQP2 levels, enuretic children with normal nocturnal AVP levels but with hypercalciuria displayed low nighttime urine AQP2 levels compared to daytime samples [226]. Moreover, a low- $\mathrm{Ca}^{2+}$ diet given to these enuretic hypercalciuric children restored AQP2 excretion and relieved enuresis in $80 \%$ of these children [225]. Although these findings suggest that high levels of $\mathrm{Ca}^{2+}$ in urine indeed contribute to the regulation of AVP-dependent water reabsorption, Raes et al. recently found that nocturnal polyuria in a group of hypercalciuric children coincided with nocturnal natriuresis, suggesting that the polyuria might be due to osmotic diuresis [185]. It would be interesting to know whether the children from the Valenti study showed the same differences in daytime-nighttime sodium excretion and whether the nocturnal enuresis in the patients from Raes et al. would be diminished when these children would receive a lowcalcium diet.

\section{Molecular regulation of AQP2 translocation}

\section{AQP2 phosphorylation}

As mentioned, a prerequisite for AVP-mediated apical translocation is the phosphorylation of AQP2 at Ser-256 by PKA $[55,109,228]$. Although each AQP2 monomer forms a functional water channel, AQP2 is expressed as a homotetramer, and phosphorylation of at least three out of four monomers is required for apical membrane localization [102]. The role of other putative phosphorylation sites in AQP2, three putative casein kinase II sites (Ser-148, Ser229, and Thr-244), and one PKC site (Ser-231) was also investigated but could not be associated with AQP2 trafficking [228]. Recently, three novel phosphorylation sites were identified in the C-terminus of AQP2, Ser-261, Ser264, and Ser-269, which are of potential importance in AVPinduced AQP2 trafficking [86]. While AVP treatment increases the phosphorylation of Ser-256 of AQP2, Hoffert et al. demonstrated that phosphorylation of Ser-261 in the AQP2 C-terminus is reduced upon AVP treatment [85]. Also, the subcellular localization of these phosphorylated proteins is distinct: While AQP2 phosphorylated at Ser-256 is predominantly expressed in the apical membrane, AQP2 phosphorylated at Ser-261 localizes subapically and gives a punctuate staining [85]. These findings suggest a role for Ser-261 phosphorylation in the trafficking of AQP2. Further investigation is required to establish a role of Ser-261 phosphorylation in AQP2 trafficking and to find out to what extent phosphorylation of Ser-264 and Ser-269 might contribute to AQP2 trafficking, translocation, and water permeability.

Calcineurin, a Ser/Thr phosphatase, might also be involved in AQP2 trafficking. Calcineurin, also known as 
protein phosphatase $2 \mathrm{~B}$, was found in a complex with AQP2 and could dephosphorylate AQP2 in vitro [97]. Paradoxically, mice lacking the $\alpha$ isoform of calcineurin A subunit were unable to concentrate their urine in response to dDAVP [64]. Accordingly, these mice showed a decrease in phosphorylated AQP2 levels in response to AVP and AQP2 appeared to be retained in an intracellular compartment. While these data indicate that phosphatase activity of calcineurin might be required for apical AQP2 translocation, its role in AQP2 regulation thus seems to be more complex than just a phosphatase that may dephosphorylate AQP2 at Ser-256.

\section{AQP2-associated proteins}

To date, only four proteins are known to directly interact with AQP2. Noda et al. identified two AQP2 interacting proteins, actin and signal-induced proliferation-associated protein 1 (SPA-1) [168, 169]. Translocation of AQP2 to the apical plasma membrane is associated with the depolymerization of the actin cytoskeleton (see below), and binding of AQP2 to actin might therefore be a key step for AQP2 translocation. SPA-1 is a specific GTPase-activating protein for Rap1 whose activity is required for AQP2 translocation to the apical membrane [168]. Interestingly, Epac 1 and 2 also activate Rap1 and have been shown to be involved in AQP2 translocation (see above). At present, however, it is unclear whether SPA-1 is involved in the Epac signaling cascade. Secondly, AQP2 interacts with heatshock protein 70 (Hsc70), which is part of the endocytotic machinery that regulates clathrin-mediated endocytosis [133]. In addition to Hsc70, AQP2 also interacts with other components of the clathrin-mediated endocytotic machinery, such as clathrin, dynamin, and the clathrin adaptor protein AP2. This is consistent with previous reports demonstrating that AQP2 is internalized via clathrin-mediated endocytosis [24, 132, 208]. Finally, a recent study by Kamsteeg et al. demonstrated that AQP2 interacts with myelin and lymphocyte-associated protein (MAL). MAL is constitutively expressed in the collecting duct apical membrane and was shown to increase AQP2 phosphorylation and decrease its internalization, thereby enhancing its apical membrane expression [101]. The interaction between $\mathrm{AQP} 2$ and MAL increases the apical membrane expression of AQP2 by decreasing AQP2 endocytosis. It will be interesting to determine whether AQP2 ubiquitination is involved and whether exocytosis from recycling endosomes is affected as well.

The microtubular network

Besides AQP2 phosphorylation, the microtubular network and cytoskeleton also play an important role in the trafficking of AQP2 bearing vesicles to the apical mem- brane. Intracellular trafficking requires a microtubular network and microtubule-associated motor proteins like dynein and dynactin of which several have been identified in AQP2-bearing vesicles [144, 178, 179]. The motor protein myosin $\mathrm{Vb}$ and its vesicular receptor Rab11 are involved in protein recycling and, recently, these proteins have been shown to play a role in AQP2 trafficking [122, 160]. Myosin Vb was shown to colocalize with AQP2 in principal cells of rat kidney slices. Upon expression of a dominant-negative myosin $\mathrm{Vb}$ mutant in AQP2-expressing CD8 cells, forskolin-induced AQP2 translocation to the apical membrane was abolished [160]. Similarly, it was demonstrated that Rab11 family interacting protein 2 (Rab11-FIP2), a protein that mediates interaction between myosin $\mathrm{Vb}$ and its vesicular receptor Rab11, plays a role in the trafficking of AQP2. A dominant-negative Rab11-FIP2 mutant, which disrupts Rab11-dependent recycling, impaired forskolin-induced AQP2 translocation to the apical membrane [160]. Thus, myosin $\mathrm{Vb}$ and Rab11-FIP2 play a role in the translocation of AQP2 to the membrane.

The cytoskeleton

Upon translocation to the apical plasma membrane, AQP2bearing vesicles finally need to fuse with the membrane. This fusion is likely mediated by soluble $N$-ethylmaleimide sensitive fusion factor attachment protein receptors (SNARE) proteins. Several SNARE proteins like syntaxin-4 and synaptosome-associated $23-\mathrm{kDa}$ protein have been found in collecting duct principal cells and are enriched in AQP2-bearing vesicles [94, 139, 140, 165]. Moreover, Gouraud et al. demonstrated that the vesicleassociated membrane protein 2 is required for AVP-induced AQP2 translocation [65].

Before being able to fuse, however, these vesicles have to pass the cytoskeleton. In mammalian collecting duct and toad bladder, vasopressin-induced AQP2 translocation to the plasma membrane is associated with depolymerization of the actin cytoskeleton [72, 202]. In this process, the small GTPase RhoA plays an important role in AQP2 translocation by modulating the actin cytoskeleton conformation. Inhibition of RhoA activity by PKA-mediated phosphorylation induces partial depolymerization of the actin cytoskeleton, thereby facilitating the translocation of AQP2-bearing vesicles to the apical membrane [114, 212, 214, 227]. AQP2 translocation also requires the EzrinRadixin-Moesin (ERM) protein moesin. ERM proteins play an important role in the regulation of F-actin cytoskeleton by cross-linking actin filaments with proteins in the plasma membrane. Tamma et al. demonstrated that functional moesin is required for AQP2 trafficking to the apical membrane [213]. ERM proteins function both upstream and downstream of the Rho GTPases and could 
therefore be affected by RhoA signaling or affects RhoA activity itself. In addition, ERM proteins might affect AQP2 trafficking by mediating the interaction of actin with AQP2.

\section{AQP2 internalization}

Upon AVP withdrawal, AQP2 is internalized from the plasma membrane and accumulates in intracellular vesicles $[108,163]$. In addition, activation of PKC by the phorbol ester 12-tetradecanoylphorbol-13-acetate causes internalization of AQP2 [228]. While phosphorylation of Ser-256 is essential for AVP-induced AQP2 translocation to the plasma membrane, dephosphorylation of AQP2 does not seem to be required for its internalization [228]. Retrieval of AQP2 from the plasma membrane was demonstrated to occur via clathrin-mediated endocytosis [24, 25]. Inhibition of clathrin-mediated endocytosis resulted in AQP2 accumulation at the plasma membrane [208].

The molecular mechanism underlying the internalization of AQP2 was not known. Recently, however, Kamsteeg et al. demonstrated that AVP removal or PKC activation by phorbol esters induces short-chain ubiquitination of AQP2, followed by endocytosis and subsequent sorting to multivesicular bodies [103]. While AQP2 has three putative attachment sites for ubiquitin (cytosolic lysines) at positions Lys-228, Lys-238, and Lys-270, analysis of cells expressing AQP2 mutants in which these lysines were replaced by arginines revealed that only Lys-270 is a substrate for ubiquitination. Consistently, AQP2-K270R was delayed in its internalization, demonstrating the importance of ubiquitination in AQP2 endocytosis [103]. However, although delayed, AQP2-K270R was still internalized, which indicated that there are other mechanisms involved in AQP2 endocytosis.

\section{AQP2-associated pathologies}

AQP2 has been demonstrated to play a role in the pathophysiology of several diseases associated with a disturbed water balance. Congestive heart failure (CHF), liver cirrhosis, and pre-ecclampsia are characterized by excessive water reabsorption. In these conditions, increased AVP levels, resulting from arterial underfilling and "suggestive" hypovolemia, induce excessive water uptake, often leading to hyponatremia. Consistently, in CHF rat models, increased AQP2 levels and clear apical plasma membrane expression were found [166, 239]. In liver cirrhosis, increased plasma AVP levels have been suggested to be responsible for impaired water excretion (reviewed in [164]). However, there are still some discrepancies between the various animal models. In several rat models of liver cirrhosis, increased AQP2 levels were found [6, 54]. In another study, however, total AQP2 levels were not changed, but an increase in plasma membrane expression of AQP2 was observed [49]. Moreover, other rat models of liver cirrhosis displayed decreased AQP2 levels and impaired water reabsorption [50, 98, 99]. An explanation for the differences found between these rat models is at present lacking.

In contrast to the conditions mentioned above, NDI is characterized by polyuria due to an AVP-induced impaired water reabsorption, and, consequently, polydipsia (reviewed in [189]).

\section{Acquired NDI}

NDI can either be acquired or present from birth (congenital). Acquired NDI was reviewed in detail recently and will only be discussed here briefly $[164,189]$. Acquired forms of NDI result from various conditions. NDI is a common side effect in $10 \%$ to $20 \%$ of patients treated with lithium, the drug of choice to treat bipolar disorders. In rats, lithium was demonstrated to induce polyuria and a downregulation of AQP2 expression, which is, at an early stage, likely mediated by a lithium-induced inhibition of cAMP production $[32,127,142]$. At later stages of disease development, lithium also induces a loss of principal cells [32]. Other causes of NDI are hypokalemia and hypercalcemia. Like lithium therapy, hypokalemia and hypercalcemia decrease AQP2 expression in rats [42, 143]. Also, urinary tract obstruction, accompanied by decreased AQP2 expression, can cause urinary concentration problems because after removal of the obstruction, AQP2 levels are still downregulated [53, 123]. Finally, acquired NDI is also seen in acute and chronic renal failure. Several studies demonstrated decreased AQP2 expression and polyuria in rat models suffering from renal failure [48, 120, 121]. Patients with chronic renal failure have severe problems with water reabsorption, regardless of vasopressin plasma levels [216].

\section{Congenital NDI}

Congenital NDI can be due to mutations in the AVPR2 gene, encoding the V2R (X-linked NDI) or mutations in the $A Q P 2$ gene (autosomal recessive or autosomal dominant NDI). More than $90 \%$ of all congenital NDI patients suffer from X-linked NDI. Mutations in the AVPR2 gene result in disturbed receptor signaling, rendering the renal principal cells insensitive to AVP, which results in a severe urine concentration defect. The molecular mechanisms underlying X-linked NDI can be divided in five different classes. The most common is misfolding of the protein and retention in the endoplasmic reticulum (ER; class II) [80, 188]. Others include (I) defective processing or unstable mRNA, (III) diminished binding of the Gs protein, (IV) 
reduced affinity for AVP, and (V) misrouting of the V2R to different organelles in the cell $[9,14,174,175,191,236]$. These defects have recently been reviewed extensively [189] and will not be discussed in more detail here.

Of all patients diagnosed with autosomal NDI, more than $90 \%$ suffers from recessive NDI. Most mutations found in recessive NDI are located in the core region of the AQP2 protein, which encompasses six transmembrane domains and five connecting loops. These mutations result in misfolded proteins that are retained in the ER and degraded rapidly $[38,128,145,147,154]$. The healthy parents of recessive NDI patients express both mutant and wild-type AQP2 proteins. Since the mutants do not tetramerize with the wild-type AQP2, as was shown for the AQP2-R187C mutation [104, 146], only homotetramers of wild-type AQP2 will be expressed on the apical membrane of the parents, allowing sufficient water reabsorption. The least occurring form of NDI, autosomal dominant NDI, is caused by mutations in the C-terminal tail of AQP2. These AQP2 mutants form heterotetramers with wild-type AQP2 and are, due to the mutation, missorted to other cellular organelles $[104,119,146,153]$. Since wild-type AQP2 is retained in mixed tetramers and missorted, water reabsorption is severely affected, explaining the dominant inheritance of NDI in these patients.

Recent mouse models reveal that the mechanisms underlying congenital NDI in vitro also apply to the in vivo situation. Complete $A Q P 2$ knockout mice, as well as recessive NDI $A Q P 2-T 126 M$ knockin mice, die within a few weeks after birth due to severe urinary concentration problems and hydronephrosis [190, 244]. Although cortical collecting duct-specific $A Q P 2$ knockout mice also demonstrated growth retardation and 10-fold increased urine production, these mice survived [190]. Several of the in vivo studies confirmed our current thoughts on congenital NDI. The AQP2-T126M knockin mice displayed a similar ER-glycosylation pattern as observed for the human mutant expressed in cells, demonstrating that ER retention also underlies recessive NDI in vivo [154, 210, 244]. Furthermore, in the first mouse model of dominant NDI, the AQP2-763-772del knockin mouse, mutant AQP2 formed heterotetramers with wild-type AQP2 and was missorted to the basolateral plasma membrane, as described for the in vitro situation [104, 146, 204].

However, different NDI mice models also provided new information on AQP2 regulation in NDI [129, 150, 190, 204, 245]. Several studies already suggested that the relative strength of the wild-type and mutant sorting signals determine the final destination of the tetramers and whether NDI is inherited as a recessive or dominant trait $[35,100]$. In two families with recessive NDI, patients appeared to be heterozygotes for $A Q P 2$ mutations of which one, AQP2P262L, was located in the AQP2 C-tail. Mutations in the
AQP2 C-tail usually cause dominant NDI [35]. In line with mutants in dominant NDI, in vitro studies demonstrated that AQP2-P262L was unable to interact with AQP2$\mathrm{R} 187 \mathrm{C}$ and did interact with wild-type AQP2. In contrast to mutants in dominant NDI, however, wild-type AQP2 rescued the misrouting of AQP2-P262L and directed the complex to the apical plasma membrane, thereby explaining the healthy phenotype of parents of the patients [35]. Interesting in this respect is that an S256L mutation in AQP2 causes recessive NDI in mice, whereas the R254L mutation causes dominant NDI in humans [36, 150]. As both mechanisms result in the lack of PKA to phosphorylate AQP2 at Ser-256, these data may be another indication that recessive or dominant NDI phenotype is determined by the strength of the apical sorting signal in wild-type AQP2 versus the strength of the missorting signal in the mutant.

Another surprising novelty from the mouse models was that mutations in the core region of AQP2 can lead to a variable level of misfolding and severity of NDI. While AQP2-T125M knockin mice die due to the lack of functional AQP2, mice with an F204V mutation in AQP2 have recessive NDI but do survive. This suggested that these mice had some residual water transport ability [129]. Indeed, while most AQP2-F204V was localized throughout the cytoplasm, some reached the membrane. Similarly, humans suffering from recessive NDI caused by a V168M mutation also demonstrate less ER retention and a less severe phenotype compared to other mutants in recessive NDI [16]. Surprisingly and in contrast to another mutant in recessive NDI, AQP2-R187C, AQP2-F204V also forms heterotetramers with wild-type AQP2 and is rescued to the plasma membrane in the heterozygote $[100,129]$. As only AQP2-R187C is tested thoroughly in vitro, it may be that some AQP2 mutants causing human NDI are also less misfolded, interact with wild-type AQP2, and are transported to the apical membrane in parents of the patients with autosomal recessive NDI.

\section{Polycystic kidney disease}

Disturbances in AQP2-mediated water transport also play a role in hereditary cyst-associated disorders such as polycystic kidney disease (PKD), Bardet-Biedl syndrome, Meckel syndrome, von Hippel-Lindau disease, and nephronophthisis, and several acquired cystic diseases $[15,51]$. Most common among these hereditary disorders is PKD, which affects one in 1,000 individuals. PKD displays an autosomal dominant (ADPKD) or autosomal recessive (ARPKD) pattern of inheritance. ADPKD is generally a late-onset disorder, characterized by the formation of multiple renal cysts, which may derive from all parts of the nephrons and collecting ducts and may cause kidney 
enlargement and may eventually result in kidney failure. In ADPKD, extrarenal manifestations such as hepatic and pancreatic cysts, cranial aneurysms and hypertension also occur. ARPKD usually becomes apparent early in life and is characterized by collecting duct-derived renal cysts, as well as liver disease. ADPKD results from mutations in the PKD1 or PKD2 gene, and these genes give rise to the membrane glycoproteins, polycystin-1 and polycystin-2 [27, 91, 152, 194]. ARPKD has been associated with mutations in the PKHDl gene, which encodes the membrane glycoprotein fibrocystin [233, 238]. Polycystin-2 acts as a $\mathrm{Ca}^{2+}$-permeable cation channel at the plasma membrane, the ER, and the primary cilia [63, 117]. Primary cilia are microtubular-based, hair-like organelles that project into the lumen of renal tubules and function as mechanosensors to detect fluid flow. Polycystin-1 is thought to be involved in the regulation and/or localization of polycystin-2 through direct interaction with this $\mathrm{Ca}^{2+}$-channel [184, 220]. Furthermore, polycystin-1 is involved in G-protein-coupled signal transduction, able to induce cell cycle arrest via activation of the JAK-STAT signaling pathway, involved in activation of NFAT signaling pathway, and, most likely, plays a role in organization of the cytoskeleton, as demonstrated by its presence in a complex together with
E-cadherin and catenins [13, 89, 177, 182]. Fibrocystin is also part of a complex with polycystin- 2 and regulates intracellular $\mathrm{Ca}^{2+}$ levels [230, 237]. All three proteins affected in PKD are located in the primary cilia, the mechanosensors of the cell [234, 249]. Upon mechanical stimulation of the cilium, $\mathrm{Ca}^{2+}$ presumably enters the cell via the polycystin-1/polycystin-2 complex and triggers the release of $\mathrm{Ca}^{2+}$ from the ER, where the majority of polycystin-2 is expressed [159]. Increased $\mathrm{Ca}^{2+}$, subsequently, initiates multiple intracellular signaling cascades.

Decreased $\mathrm{Ca}^{2+}$ levels, disruption of the $\mathrm{Ca}^{2+}$-dependent signaling pathways, and subsequent accumulation of cAMP are thought to be the key factor in the formation of cysts, which is characterized by increased cell proliferation and apoptosis, a mitogenic response to increased cAMP and increased fluid secretion (Fig. 3; reviewed in [218]).

In normal renal epithelial cells, cAMP inhibits cell proliferation and growth and stimulates fluid reabsorption. In PKD-derived cells, however, the accumulation of cAMP promotes cell proliferation, growth, and fluid secretion [12, $69,141,241]$. In cells derived from polycystic kidneys, cAMP activates B-Raf, which in turn stimulates the MAPK/ ERK signaling pathway, leading to cell proliferation [241, 242]. In contrast, cAMP inhibits B-Raf and ERK activity in

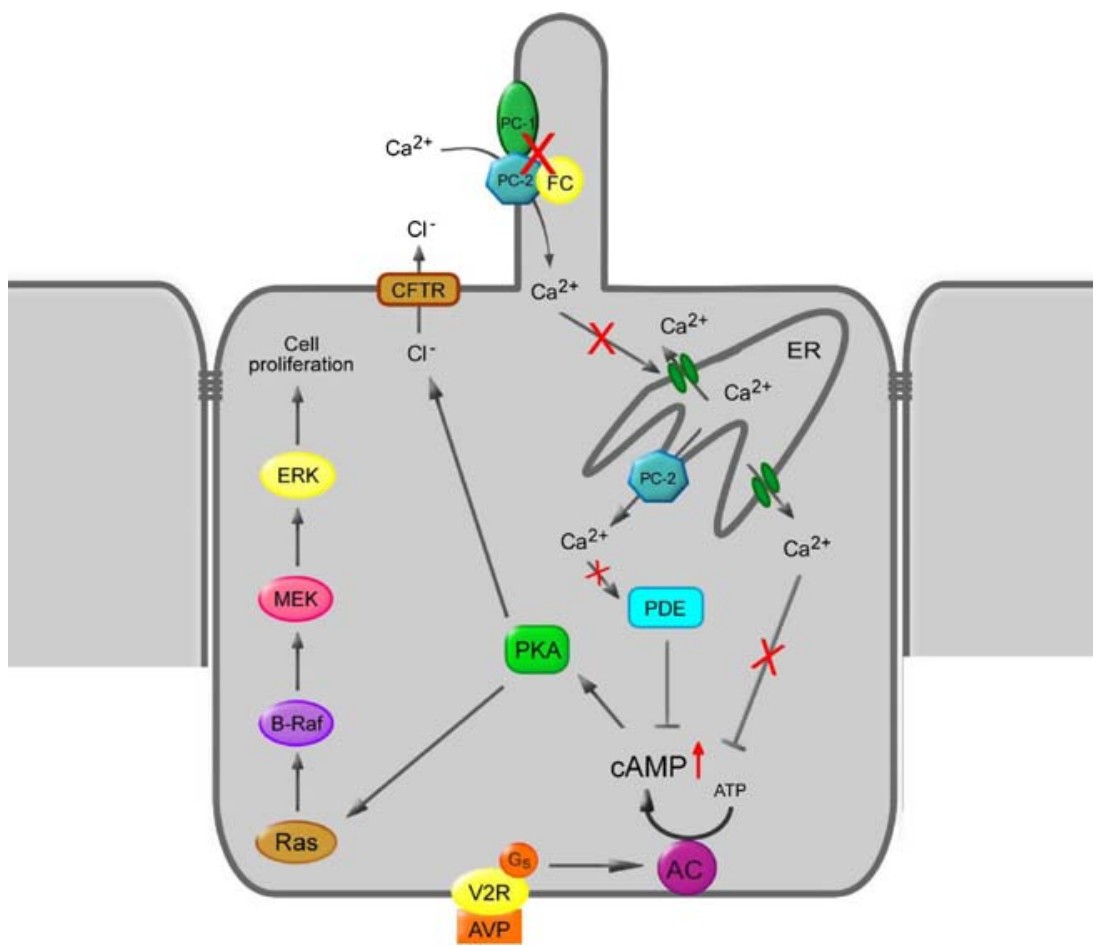

Fig. 3 Model of the pathways involved in polycystic kidney disease. Upon mechanical stimulation of the primary cilium, $\mathrm{Ca}^{2+}$ enters the cell via polycystin-2 $(P C-2)$, which forms a complex with polycystin-1 $(P C-1)$ and fibrocystin $(F C)$. In addition, $\mathrm{Ca}^{2+}$ is released from the endoplasmatic reticulum $(E R)$. Disruption of the polycystin/fibrocystin pathway results in decreased cytosolic $\mathrm{Ca}^{2+}$ levels. Reduced $\mathrm{Ca}^{2+}$ levels stimulate adenylate cyclase $(A C)$ and inhibit phosphodiesterase $(P D E)$, resulting in increased cAMP levels. Subsequent activation of protein kinase A $(P K A)$ stimulates cell proliferation by sequential activation of Ras, B-Raf, MEK, and ERK. Furthermore, in polycystic kidney disease, cAMP-PKA signaling increases the permeability and expression of CFTR $\mathrm{Cl}^{-}$channels, resulting in $\mathrm{Cl}^{-}$extrusion. This increases the movement of $\mathrm{Na}$ and, subsequently, water into the lumen of the cyst 
normal kidney cells, thereby repressing cell proliferation. In addition to cyst proliferation, cAMP accumulation also stimulates secretion of fluid into the lumen of the cyst. $\mathrm{Cl}^{-}$ enters the principal cells via the $\mathrm{Na}-\mathrm{K}-2 \mathrm{Cl}^{-}$(NKCC1) cotransporter, expressed on the basolateral membrane, and is extruded into the lumen via the apically localized cystic fibrosis transmembrane conductance regulator (CFTR) $\mathrm{Cl}^{-}$ channel whose cAMP-mediated permeability and expression is increased in PKD [34, 68, 92, 138]. The resulting negative lumen potential increases the movement of $\mathrm{Na}$ into the lumen, which then causes an osmotically driven water flux into the lumen of the cyst. ATP, which is secreted into the cyst lumen, was demonstrated to stimulate $\mathrm{Cl}^{-}$secretion and thus may contribute to cyst expansion [200]. Several $\mathrm{P} 2 \mathrm{Y}$ and $\mathrm{P} 2 \mathrm{X}$ receptors are expressed in cells derived from PKD cysts [82, 200, 222]. Although P2X7-mediated signaling seemed to reduce the development of cysts [83], a recent study demonstrated that inhibition of endogenous P2Y receptors decreases the growth of MDCK-derived cysts, suggesting a role for P2Y-mediated ATP signaling in renal cystic diseases [221].

A decreased intracellular $\mathrm{Ca}^{2+}$ concentration appears to play a pivotal role in cyst development since increasing these calcium levels was shown to restore the normal phenotype in polycystic cells [240]. The effect of intracellular $\mathrm{Ca}^{2+}$ concentration on cAMP levels could be mediated by activation of AC6, which is present not only in principal cells but also in cilia and is repressed by $\mathrm{Ca}^{2+}[77,148]$. Recently, a molecule closely resembling forskolin, an activator of AC, was identified in collected cyst fluid, raising the possibility that this molecule also contributes to cAMP formation and, consequently, cyst expansion [183]. The origin of this molecule has not been reported yet. The decreased $\mathrm{Ca}^{2+}$ concentration may also increase cAMP levels by inhibiting $\mathrm{Ca}^{2+}$-dependent PDE1, which is also localized in collecting duct [243]. Humans diagnosed with ADPKD or ARPKD, as well as animal models for PKD, suffer from a renal concentrating defect. A mouse model of ARPKD was found to lack a medullary-concentrating gradient, which could contribute to the urine concentration defect in these mice [58]. The lack of such a concentrating gradient may result from the distortion of the medullary structure in cystic kidneys. One could also speculate that the concentration defect results from decreased collecting duct expression of genes involved in urine concentration. Instead, increased levels of AVP and upregulation of V2R and AQP2 expression were found in the cystic kidneys of mice [58]. Inhibition of V2R signaling by using a V2R antagonist lowered cAMP levels and diminished the formation and expansion of renal cysts [58, 59, 219, 232]. In addition, decreasing the plasma AVP levels by increased water intake suppressed cAMP-dependent B-Raf/MEK/ ERK activity and proliferation and slowed the progression of cystic disease in a rat model of PKD [158]. Although homozygous $P K D 1$ knockout mice models are embryonically lethal, heterozygous $P K D 1$ mice have a normal phenotype, with the exception of a limited amount of cysts at very old age $[20,111,134,135]$. Therefore, this model was used to test whether the observed changes in water handling and V2R signaling occur prior to cyst development [1]. Although cAMP levels and both AQP2 and V2R mRNA levels were unaffected, these heterozygous PKD1 mice showed inappropriate antidiuresis associated with lowered intracellular $\mathrm{Ca}^{2+}$ concentration, a decrease in phosporylated ERK, suppressed RhoA activity, and clear translocation of AQP2 to the apical membrane of collecting duct principal cells [1]. This study suggests a potential role for polycystin-1 in $\mathrm{Ca}^{2+}$-signaling and AQP2 trafficking in renal collecting duct.

\section{Concluding remarks}

The role of the AQP2 water channel in vasopressinregulated water reabsorption has been studied intensively since its original discovery in 1993. Tremendous efforts increased our knowledge of the importance of hormoneinduced AQP2 shuttling to and from the apical plasma membrane and its underlying molecular mechanisms extensively. Besides its well-defined role in the pathophysiology of NDI, AQP2-mediated water transport has been increasingly associated with disorders characterized by excessive water reabsorption. Current research focuses on the quest for therapeutic compounds useful in the treatment of such disorders.

Acknowledgments This work was supported by grants from the Dutch Kidney Foundation (C03-2060) and the UMCN (2004-55) to P.M.T.D.

Open Access This article is distributed under the terms of the Creative Commons Attribution Noncommercial License which permits any noncommercial use, distribution, and reproduction in any medium, provided the original author(s) and source are credited.

\section{References}

1. Ahrabi AK, Terryn S, Valenti G, Caron N, Serradeil-Le GC, Raufaste D, Nielsen S, Horie S, Verbavatz JM, Devuyst O (2007) PKD1 haploinsufficiency causes a syndrome of inappropriate antidiuresis in mice. J Am Soc Nephrol 18:1740-1753

2. Alfie ME, Alim S, Mehta D, Shesely EG, Carretero OA (1999) An enhanced effect of arginine vasopressin in bradykinin B2 receptor null mutant mice. Hypertension 33:1436-1440

3. Ando Y, Asano Y (1993) Functional evidence for an apical V1 receptor in rabbit cortical. Am J Physiol 264:F467-F471 
4. Ando Y, Tabei K, Asano Y (1991) Luminal vasopressin modulates transport in the rabbit cortical collecting duct. J Clin Invest 88:952-959

5. Aromataris EC, Roberts ML, Barritt GJ, Rychkov GY (2006) Glucagon activates $\mathrm{Ca} 2$ and $\mathrm{Cl}-$ channels in rat hepatocytes. J Physiol 573:611-625

6. Asahina Y, Izumi N, Enomoto N, Sasaki S, Fushimi K, Marumo F, Sato C (1995) Increased gene expression of water channel in cirrhotic rat kidneys. Hepatology 21:169-173

7. Bailey MA, Imbert-Teboul M, Turner C, Marsy S, Srai K, Burnstock G, Unwin RJ (2000) Axial distribution and characterization of basolateral $\mathrm{P} 2 \mathrm{Y}$ receptors along the rat renal tubule. Kidney Int 58:1893-1901

8. Bankir L (2001) Antidiuretic action of vasopressin: quantitative aspects and interaction between V1a and V2 receptor-mediated effects. Cardiovasc Res 51:372-390

9. Barak LS, Oakley RH, Laporte SA, Caron MG (2001) Constitutive arrestin-mediated desensitization of a human vasopressin receptor mutant associated with nephrogenic diabetes insipidus. Proc Natl Acad Sci USA 98:93-98

10. Barclay JW, Morgan A, Burgoyne RD (2005) Calcium-dependent regulation of exocytosis. Cell Calcium 38:343-353

11. Beene DL, Scott JD (2007) A-kinase anchoring proteins take shape. Curr Opin Cell Biol 19:192-198

12. Belibi FA, Reif G, Wallace DP, Yamaguchi T, Olsen L, Li H, Helmkamp GM Jr, Grantham JJ (2004) Cyclic AMP promotes growth and secretion in human polycystic kidney epithelial cells. Kidney Int 66:964-973

13. Bhunia AK, Piontek K, Boletta A, Liu L, Qian F, Xu PN, Germino FJ, Germino GG (2002) PKD1 induces p21(waf1) and regulation of the cell cycle via direct activation of the JAKSTAT signaling pathway in a process requiring PKD2. Cell 109:157-168

14. Birnbaumer M, Gilbert S, Rosenthal W (1994) An extracellular congenital nephrogenic diabetes insipidus mutation. Mol Endocrinol 8:886-894

15. Bisceglia M, Galliani CA, Senger C, Stallone C, Sessa A (2006) Renal cystic diseases: a review. Adv Anat Pathol 13:26-56

16. Boccalandro C, De Mattia F, Guo DC, Xue L, Orlander P, King TM, Gupta P, Deen PMT, Lavis VR, Milewicz DM (2004) Characterization of an aquaporin-2 water channel gene mutation causing partial nephrogenic diabetes insipidus in a Mexican family: evidence of increased frequency of the mutation in the town of origin. J Am Soc Nephrol 15:1223-1231

17. Bos JL (2006) Epac proteins: multi-purpose cAMP targets. Trends Biochem Sci 31:680-686

18. Bouley R, Breton S, Sun T, McLaughlin M, Nsumu NN, Lin HY, Ausiello DA, Brown D (2000) Nitric oxide and atrial natriuretic factor stimulate cGMP-dependent membrane insertion of aquaporin 2 in renal epithelial cells. J Clin Invest 106:1115-1126

19. Bouley R, Pastor-Soler N, Cohen O, McLaughlin M, Breton S, Brown D (2005) Stimulation of AQP2 membrane insertion in renal epithelial cells in vitro and in vivo by the cGMP phosphodiesterase inhibitor sildenafil citrate (Viagra). Am J Physiol Renal Physiol 288:F1103-F1112

20. Boulter C, Mulroy S, Webb S, Fleming S, Brindle K, Sandford R (2001) Cardiovascular, skeletal, and renal defects in mice with a targeted disruption of the Pkd1 gene. Proc Natl Acad Sci USA 98:12174-12179

21. Bourque CW, Oliet SH, Richard D (1994) Osmoreceptors, osmoreception, and osmoregulation. Front Neuroendocrinol $15: 231-274$

22. Breyer MD, Breyer RM (2001) G protein-coupled prostanoid receptors and the kidney. Annu Rev Physiol 63:579-605

23. Breyer MD, Jacobson HR, Breyer JA (1988) Epidermal growth factor inhibits the hydroosmotic effect of vasopressin in the isolated perfused rabbit cortical collecting tubule. J Clin Invest 82:1313-1320

24. Brown D, Orci L (1983) Vasopressin stimulates formation of coated pits in rat kidney collecting ducts. Nature 302:253-255

25. Brown D, Weyer P, Orci L (1988) Vasopressin stimulates endocytosis in kidney collecting duct principal cells. Eur J Cell Biol 46:336-341

26. Bustamante M, Hasler U, Kotova O, Chibalin AV, Mordasini D, Rousselot M, Vandewalle A, Martin PY, Feraille E (2005) Insulin potentiates AVP-induced AQP2 expression in cultured renal collecting duct principal cells. Am J Physiol Renal Physiol 288:F334-F344

27. Cai Y, Maeda Y, Cedzich A, Torres VE, Wu G, Hayashi T, Mochizuki T, Park JH, Witzgall R, Somlo S (1999) Identification and characterization of polycystin-2, the PKD2 gene product. J Biol Chem 274:28557-28565

28. Carlisle Michel JJ, Dodge KL, Wong W, Mayer NC, Langeberg LK, Scott JD (2004) PKA-phosphorylation of PDE4D3 facilitates recruitment of the mAKAP signalling complex. Biochem $\mathrm{J}$ 381:587-592

29. Champigneulle A, Siga E, Vassent G, Imbert-Teboul M (1993) V2-like vasopressin receptor mobilizes intracellular $\mathrm{Ca} 2$ in rat medullary collecting tubules. Am J Physiol 265:F35-F45

30. Charest PG, Oligny-Longpre G, Bonin H, Azzi M, Bouvier M (2006) The V2 vasopressin receptor stimulates ERK1/2 activity independently of heterotrimeric $G$ protein signalling. Cell Signal 19:32-41

31. Chou CL, Yip KP, Michea L, Kador K, Ferraris JD, Wade JB, Knepper MA (2000) Regulation of aquaporin-2 trafficking by vasopressin in renal collecting duct: roles of ryandoine-sensitive Ca2 stores and calmodulin. J Biol Chem 275:36839-36846

32. Christensen BM, Marples D, Kim YH, Wang W, Frokiaer J, Nielsen S (2004) Changes in cellular composition of kidney collecting duct cells in rats with lithium-induced NDI. Am J Physiol Cell Physiol 286:C952-C964

33. Chu JY, Chung SC, Lam AK, Tam S, Chung SK, Chow BK (2007) Phenotypes developed in secretin receptor-null mice indicated a role for secretin in regulating renal water reabsorption. Mol Cell Biol 27:2499-2511

34. Davidow CJ, Maser RL, Rome LA, Calvet JP, Grantham JJ (1996) The cystic fibrosis transmembrane conductance regulator mediates transepithelial fluid secretion by human autosomal dominant polycystic kidney disease epithelium in vitro. Kidney Int 50:208-218

35. De Mattia F, Savelkoul PJ, Bichet DG, Kamsteeg EJ, Konings IB, Marr N, Arthus MF, Lonergan M, van Os CH, van der SP, Robertson G, Deen PM (2004) A novel mechanism in recessive nephrogenic diabetes insipidus: wild-type aquaporin-2 rescues the apical membrane expression of intracellularly retained AQP2-P262L. Hum Mol Genet 13:3045-3056

36. De Mattia F, Savelkoul PJ, Kamsteeg EJ, Konings IB, van der SP, Mallmann R, Oksche A, Deen PM (2005) Lack of arginine vasopressin-induced phosphorylation of aquaporin-2 mutant AQP2-R254L explains dominant nephrogenic diabetes insipidus. J Am Soc Nephrol 16:2872-2880

37. de Rooij J, Zwartkruis FJ, Verheijen MH, Cool RH, Nijman SM, Wittinghofer A, Bos JL (1998) Epac is a Rap1 guaninenucleotide-exchange factor directly activated by cyclic AMP. Nature 396:474-477

38. Deen PMT, Croes H, van Aubel RA, Ginsel LA, van Os CH (1995) Water channels encoded by mutant aquaporin-2 genes in nephrogenic diabetes insipidus are impaired in their cellular routing. J Clin Invest 95:2291-2296

39. Dillingham MA, Anderson RJ (1986) Inhibition of vasopressin action by atrial natriuretic factor. Science 231:1572-1573

40. Dodge-Kafka KL, Soughayer J, Pare GC, Carlisle Michel JJ, Langeberg LK, Kapiloff MS, Scott JD (2005) The protein kinase 
A anchoring protein mAKAP coordinates two integrated cAMP effector pathways. Nature 437:574-578

41. Dousa TP (1999) Cyclic-3ф,5ф-nucleotide phosphodiesterase isozymes in cell biology and pathophysiology of the kidney. Kidney Int 55:29-62

42. Earm JH, Christensen BM, Frokiaer J, Marples D, Han JS, Knepper MA, Nielsen S (1998) Decreased aquaporin-2 expression and apical plasma membrane delivery in kidney collecting ducts of polyuric hypercalcemic rats. J Am Soc Nephrol 9:21812193

43. Ecelbarger CA, Chou CL, Lolait SJ, Knepper MA, Digiovanni SR (1996) Evidence for dual signaling pathways for V-2 vasopressin receptor in rat inner medullary collecting duct. Am J Physiol 39:F623-F633

44. Ecelbarger CA, Maeda Y, Gibson CC, Knepper MA (1994) Extracellular ATP increases intracellular calcium in rat terminal collecting duct via a nucleotide receptor. Am J Physiol 267: F998-F1006

45. Edwards RM (2002) Basolateral, but not apical, ATP inhibits vasopressin action in rat inner medullary collecting duct. Eur $\mathrm{J}$ Pharmacol 438:179-181

46. Edwards RM, Brooks DP (2001) Dopamine inhibits vasopressin action in the rat inner medullary collecting duct via alpha(2)adrenoceptors. J Pharmacol Exp Ther 298:1001-1006

47. Edwards RM, Stack EJ, Pullen M, Nambi P (1993) Endothelin inhibits vasopressin action in rat inner medullary collecting duct via the ETB receptor. J Pharmacol Exp Ther 267:1028-1033

48. Fernandez-Llama P, Andrews P, Turner R, Saggi S, Dimari J, Kwon TH, Nielsen S, Safirstein R, Knepper MA (1999) Decreased abundance of collecting duct aquaporins in postischemic renal failure in rats. J Am Soc Nephrol 10:1658-1668

49. Fernandez-Llama P, Jimenez W, Bosch-Marce M, Arroyo V, Nielsen S, Knepper MA (2000) Dysregulation of renal aquaporins and $\mathrm{Na}-\mathrm{Cl}$ cotransporter in $\mathrm{CCl} 4-$ induced cirrhosis. Kidney Int 58:216-228

50. Fernandez-Llama P, Turner R, Dibona G, Knepper MA (1999) Renal expression of aquaporins in liver cirrhosis induced by chronic common bile duct ligation in rats. J Am Soc Nephrol 10:1950-1957

51. Fick GM, Gabow PA (1994) Hereditary and acquired cystic disease of the kidney. Kidney Int 46:951-964

52. Fleming EF, Athirakul K, Oliverio MI, Key M, Goulet J, Koller BH, Coffman TM (1998) Urinary concentrating function in mice lacking EP3 receptors for prostaglandin E2. Am J Physiol 275: F955-F961

53. Frokiaer J, Marples D, Knepper MA, Nielsen S (1996) Bilateral ureteral obstruction downregulates expression of vasopressinsensitive AQP-2 water channel in rat kidney. Am J Physiol 39: F657-F668

54. Fujita N, Ishikawa S, Sasaki S, Fujisawa G, Fushimi K, Marumo F, Saito T (1995) Role of water channel AQP-CD in water retention in SIADH and cirrhotic rats. Am J Physiol 38:F926-F931

55. Fushimi K, Sasaki S, Marumo F (1997) Phosphorylation of serine 256 is required for cAMP- dependent regulatory exocytosis of the aquaporin-2 water channel. J Biol Chem 272:14800-14804

56. Garcia NH, Garvin JL (1994) Endothelin's biphasic effect on fluid absorption in the proximal straight tubule and its inhibitory cascade. J Clin Invest 93:2572-2577

57. Garvin J, Sanders K (1991) Endothelin inhibits fluid and bicarbonate transport in part by reducing $\mathrm{Na}+/ \mathrm{K}+$ ATPase activity in the rat proximal straight tubule. J Am Soc Nephrol 2:976-982

58. Gattone VH, Maser RL, Tian C, Rosenberg JM, Branden MG (1999) Developmental expression of urine concentration-associated genes and their altered expression in murine infantile-type polycystic kidney disease. Dev Genet 24:309-318
59. Gattone VH, Wang X, Harris PC, Torres VE (2003) Inhibition of renal cystic disease development and progression by a vasopressin V2 receptor antagonist. Nat Med 9:1323-1326

60. Ge Y, Ahn D, Stricklett PK, Hughes AK, Yanagisawa M, Verbalis JG, Kohan DE (2005) Collecting duct-specific knockout of endothelin-1 alters vasopressin regulation of urine osmolality. Am J Physiol Renal Physiol 288:F912-F920

61. Ge Y, Bagnall A, Stricklett PK, Strait K, Webb DJ, Kotelevtsev Y, Kohan DE (2006) Collecting duct-specific knockout of the endothelin $\mathrm{B}$ receptor causes hypertension and sodium retention. Am J Physiol Renal Physiol 291:F1274-F1280

62. Ge Y, Stricklett PK, Hughes AK, Yanagisawa M, Kohan DE (2005) Collecting duct-specific knockout of the endothelin A receptor alters renal vasopressin responsiveness, but not sodium excretion or blood pressure. Am J Physiol Renal Physiol 289: F692-F698

63. Gonzalez-Perrett S, Kim K, Ibarra C, Damiano AE, Zotta E, Batelli M, Harris PC, Reisin IL, Arnaout MA, Cantiello HF (2001) Polycystin-2, the protein mutated in autosomal dominant polycystic kidney disease (ADPKD), is a $\mathrm{Ca} 2$-permeable nonselective cation channel. Proc Natl Acad Sci USA 98:11821187

64. Gooch JL, Guler RL, Barnes JL, Toro JJ (2006) Loss of calcineurin Aalpha results in altered trafficking of AQP2 and in nephrogenic diabetes insipidus. J Cell Sci 119:2468-2476

65. Gouraud S, Laera A, Calamita G, Carmosino M, Procino G, Rossetto O, Mannucci R, Rosenthal W, Svelto M, Valenti G (2002) Functional involvement of VAMP/synaptobrevin-2 in cAMP-stimulated aquaporin 2 translocation in renal collecting duct cells. J Cell Sci 115:3667-3674

66. Guo X, Yang T (2006) Endothelin B receptor antagonism in the rat renal medulla reduces urine flow rate and sodium excretion. Exp Biol Med (Maywood) 231:1001-1005

67. Han JS, Maeda Y, Ecelbarger C, Knepper MA (1994) Vasopressinindependent regulation of collecting duct water permeability. Am J Physiol 266:F139-F146

68. Hanaoka K, Devuyst O, Schwiebert EM, Wilson PD, Guggino WB (1996) A role for CFTR in human autosomal dominant polycystic kidney disease. Am J Physiol 270:C389-C399

69. Hanaoka K, Guggino WB (2000) cAMP regulates cell proliferation and cyst formation in autosomal polycystic kidney disease cells. J Am Soc Nephrol 11:1179-1187

70. Hasler U, Jeon US, Kim JA, Mordasini D, Kwon HM, Feraille E, Martin PY (2006) Tonicity-responsive enhancer binding protein is an essential regulator of aquaporin-2 expression in renal collecting duct principal cells. J Am Soc Nephrol 17:1521-1531

71. Hay JC (2007) Calcium: a fundamental regulator of intracellular membrane fusion? EMBO Rep 8:236-240

72. Hays RM, Condeelis J, Gao Y, Simon H, Ding G, Franki N (1993) The effect of vasopressin on the cytoskeleton of the epithelial cell. Pediatr Nephrol 7:672-679

73. Hebert RL (1994) Cellular signalling of PGE2 and its selective receptor analogue sulprostone in rabbit cortical collecting duct. Prostaglandins Leukot Essent Fatty Acids 51:147-155

74. Hebert RL, Jacobson HR, Breyer MD (1990) PGE2 inhibits AVP-induced water flow in cortical collecting ducts by protein kinase C activation. Am J Physiol 259:F318-F325

75. Hebert RL, Jacobson HR, Breyer MD (1991) Prostaglandin E2 inhibits sodium transport in rabbit cortical collecting duct by increasing intracellular calcium. J Clin Invest 87:1992-1998

76. Hebert RL, Jacobson HR, Fredin D, Breyer MD (1993) Evidence that separate PGE2 receptors modulate water and sodium transport in rabbit cortical collecting duct. Am J Physiol 265: F643-F650

77. Helies-Toussaint C, Aarab L, Gasc JM, Verbavatz JM, Chabardes D (2000) Cellular localization of type 5 and type 6 ACs in 
collecting duct and regulation of cAMP synthesis. Am J Physiol Renal Physiol 279:F185-F194

78. Helms MN, Chen XJ, Ramosevac S, Eaton DC, Jain L (2006) Dopamine regulation of amiloride-sensitive sodium channels in lung cells. Am J Physiol Lung Cell Mol Physiol 290:L710-L722

79. Henn V, Edemir B, Stefan E, Wiesner B, Lorenz D, Theilig F, Schmitt R, Vossebein L, Tamma G, Beyermann M, Krause E, Herberg FW, Valenti G, Bachmann S, Rosenthal W, Klussmann E (2004) Identification of a novel A-kinase anchoring protein 18 isoform and evidence for its role in the vasopressin-induced aquaporin-2 shuttle in renal principal cells. J Biol Chem 279:26654-26665

80. Hermosilla R, Oueslati M, Donalies U, Schonenberger E, Krause E, Oksche A, Rosenthal W, Schulein R (2004) Disease-causing V Vasopressin Receptors are Retained in Different Compartments of the Early Secretory Pathway. Traffic 5:993-1005

81. Herrera M, Silva G, Garvin JL (2006) A high-salt diet dissociates NO synthase-3 expression and NO production by the thick ascending limb. Hypertension 47:95-101

82. Hillman KA, Johnson TM, Winyard PJ, Burnstock G, Unwin RJ, Woolf AS (2002) P2X(7) receptors are expressed during mouse nephrogenesis and in collecting duct cysts of the cpk/cpk mouse. Exp Nephrol 10:34-42

83. Hillman KA, Woolf AS, Johnson TM, Wade A, Unwin RJ, Winyard PJ (2004) The P2X7 ATP receptor modulates renal cyst development in vitro. Biochem Biophys Res Commun 322:434439

84. Hoffert JD, Chou CL, Fenton RA, Knepper MA (2005) Calmodulin is required for vasopressin-stimulated increase in cyclic AMP production in inner medullary collecting duct. J Biol Chem 280:13624-13630

85. Hoffert JD, Nielsen J, Yu MJ, Pisitkun T, Schleicher SM, Nielsen S, Knepper MA (2007) Dynamics of aquaporin-2 serine-261 phosphorylation in response to short-term vasopressin treatment in collecting duct. Am J Physiol Renal Physiol 292:F691-F700

86. Hoffert JD, Pisitkun T, Wang G, Shen RF, Knepper MA (2006) Quantitative phosphoproteomics of vasopressin-sensitive renal cells: regulation of aquaporin-2 phosphorylation at two sites. Proc Natl Acad Sci USA 103:7159-7164

87. Hoffman A, Abassi ZA, Brodsky S, Ramadan R, Winaver J (2000) Mechanisms of big endothelin-1-induced diuresis and natriuresis: role of ET(B) receptors. Hypertension 35:732-739

88. Homma S, Gapstur SM, Coffey A, Valtin H, Dousa TP (1991) Role of cAMP-phosphodiesterase isozymes in pathogenesis of murine nephrogenic diabetes insipidus. Am J Physiol 261:F345-F353

89. Huan Y, van AJ (1999) Polycystin-1, the PKD1 gene product, is in a complex containing E-cadherin and the catenins. J Clin Invest 104:1459-1468

90. Hughes AK, Stricklett PK, Kishore BK, Kohan DE (2006) Adenosine triphosphate inhibits endothelin-1 production by rat inner medullary collecting duct cells. Exp Biol Med (Maywood) 231:1006-1009

91. Hughes J, Ward CJ, Peral B, Aspinwall R, Clark K, San Millan JL, Gamble V, Harris PC (1995) The polycystic kidney disease 1 (PKD1) gene encodes a novel protein with multiple cell recognition domains. Nat Genet 10:151-160

92. Ikeda M, Fong P, Cheng J, Boletta A, Qian F, Zhang XM, Cai H, Germino GG, Guggino WB (2006) A regulatory role of polycystin-1 on cystic fibrosis transmembrane conductance regulator plasma membrane expression. Cell Physiol Biochem 18:9-20

93. Ikeda M, Yoshitomi K, Imai M, Kurokawa K (1994) Cell Ca2 response to luminal vasopressin in cortical collecting tubule principal cells. Kidney Int 45:811-816

94. Inoue T, Nielsen S, Mandon B, Terris J, Kishore BK, Knepper MA (1998) SNAP-23 in rat kidney: colocalization with aquaporin-2 in collecting duct vesicles. Am J Physiol 275:F752-F760
95. Jackson BA, Edwards RM, Valtin H, Dousa TP (1980) Cellular action of vasopressin in medullary tubules of mice with hereditary nephrogenic diabetes insipidus. J Clin Invest 66:110-122

96. Jeon US, Joo KW, Na KY, Kim YS, Lee JS, Kim J, Kim GH, Nielsen S, Knepper MA, Han JS (2003) Oxytocin induces apical and basolateral redistribution of aquaporin-2 in rat kidney. Nephron Exp Nephrol 93:e36-e45

97. Jo I, Ward DT, Baum MA, Scott JD, Coghlan VM, Hammond TG, Harris HW (2001) AQP2 is a substrate for endogenous PP2B activity within an inner medullary AKAP-signaling complex. Am J Physiol Renal Physiol 281:F958-F965

98. Jonassen TE, Nielsen S, Christensen S, Petersen JS (1998) Decreased vasopressin-mediated renal water reabsorption in rats with compensated liver cirrhosis. Am J Physiol 275: F216-F225

99. Jonassen TE, Promeneur D, Christensen S, Petersen JS, Nielsen S (2000) Decreased vasopressin-mediated renal water reabsorption in rats with chronic aldosterone-receptor blockade. Am J Physiol Renal Physiol 278:F246-F256

100. Kamsteeg EJ, Bichet DG, Konings IB, Nivet H, Lonergan M, Arthus MF, van Os CH, Deen PMT (2003) Reversed polarized delivery of an aquaporin-2 mutant causes dominant nephrogenic diabetes insipidus. J Cell Biol 163:1099-1109

101. Kamsteeg EJ, Duffield AS, Konings IB, Spencer J, Pagel P, Deen PM, Caplan MJ (2007) MAL decreases the internalization of the aquaporin-2 water channel. Proc Natl Acad Sci USA 104:16696-16701

102. Kamsteeg EJ, Heijnen I, van Os CH, Deen PMT (2000) The subcellular localization of an aquaporin-2 tetramer depends on the stoichiometry of phosphorylated and nonphosphorylated monomers. J Cell Biol 151:919-930

103. Kamsteeg EJ, Hendriks G, Boone M, Konings IB, Oorschot V, van der SP, Klumperman J, Deen PM (2006) Short-chain ubiquitination mediates the regulated endocytosis of the aquaporin-2 water channel. Proc Natl Acad Sci USA 103:1834418349

104. Kamsteeg EJ, Wormhoudt TA, Rijss JPL, van Os CH, Deen PMT (1999) An impaired routing of wild-type aquaporin-2 after tetramerization with an aquaporin-2 mutant explains dominant nephrogenic diabetes insipidus. EMBO J 18:2394-2400

105. Kang G, Chepurny OG, Malester B, Rindler MJ, Rehmann H, Bos JL, Schwede F, Coetzee WA, Holz GG (2006) cAMP sensor Epac as a determinant of ATP-sensitive potassium channel activity in human pancreatic beta cells and rat INS-1 cells. J Physiol 573:595-609

106. Kang G, Joseph JW, Chepurny OG, Monaco M, Wheeler MB, Bos JL, Schwede F, Genieser HG, Holz GG (2003) Epacselective cAMP analog 8-pCPT-2ф-O-Me-cAMP as a stimulus for $\mathrm{Ca} 2$-induced $\mathrm{Ca} 2$ release and exocytosis in pancreatic betacells. J Biol Chem 278:8279-8285

107. Kasono K, Saito T, Saito T, Tamemoto H, Yanagidate C, Uchida S, Kawakami M, Sasaki S, Ishikawa SE (2005) Hypertonicity regulates the aquaporin-2 promoter independently of arginine vasopressin. Nephrol Dial Transplant 20:509-515

108. Katsura T, Ausiello DA, Brown D (1996) Direct demonstration of aquaporin-2 water channel recycling in stably transfected LLC-PK1 epithelial cells. Am J Physiol 39:F548-F553

109. Katsura T, Gustafson CE, Ausiello DA, Brown D (1997) Protein kinase A phosphorylation is involved in regulated exocytosis of aquaporin-2 in transfected LLC-PK1 cells. Am J Physiol 41: F816-F822

110. Kennedy CR, Xiong H, Rahal S, Vanderluit J, Slack RS, Zhang Y, Guan Y, Breyer MD, Hebert RL (2007) Urine concentrating defect in prostaglandin EP1-deficient mice. Am J Physiol Renal Physiol 292:F868-F875 
111. Kim K, Drummond I, Ibraghimov-Beskrovnaya O, Klinger K, Arnaout MA (2000) Polycystin 1 is required for the structural integrity of blood vessels. Proc Natl Acad Sci USA 97:1731-1736

112. Kishore BK, Chou CL, Knepper MA (1995) Extracellular nucleotide receptor inhibits AVP-stimulated water permeability in inner medullary collecting duct. Am J Physiol 38:F863-F869

113. Kishore BK, Krane CM, Miller RL, Shi H, Zhang P, Hemmert A, Sun R, Nelson RD (2005) P2Y2 receptor mRNA and protein expression is altered in inner medullas of hydrated and dehydrated rats: relevance to AVP-independent regulation of IMCD function. Am J Physiol Renal Physiol 288:F1164-F1172

114. Klussmann E, Tamma G, Lorenz D, Wiesner B, Maric K, Hofmann F, Aktories K, Valenti G, Rosenthal W (2001) An inhibitory role of Rho in the vasopressin-mediated translocation of aquaporin-2 into cell membranes of renal principal cells. J Biol Chem 276:20451-20457

115. Knepper MA (1997) Molecular physiology of urinary concentrating mechanism: Regulation of aquaporin water channels by vasopressin. Am J Physiol 41:F3-F12

116. Kohan DE (2006) The renal medullary endothelin system in control of sodium and water excretion and systemic blood pressure. Curr Opin Nephrol Hypertens 15:34-40

117. Koulen P, Cai Y, Geng L, Maeda Y, Nishimura S, Witzgall R, Ehrlich BE, Somlo S (2002) Polycystin-2 is an intracellular calcium release channel. Nat Cell Biol 4:191-197

118. Kusano E, Yoshida I, Takeda S, Homma S, Yusufi AN, Dousa TP, Asano Y (2001) Nephron distribution of total low Km cyclic AMP phosphodiesterase in mouse, rat and rabbit kidney. Tohoku J Exp Med 193:207-220

119. Kuwahara $\mathrm{M}$, Iwai $\mathrm{K}$, Ooeda $\mathrm{T}$, Igarashi $\mathrm{T}$, Ogawa $\mathrm{E}$, Katsushima Y, Shinbo I, Uchida S, Terada Y, Arthus MF, Lonergan M, Fujiwara TM, Bichet DG, Marumo F, Sasaki S (2001) Three families with autosomal dominant nephrogenic diabetes insipidus caused by aquaporin- 2 mutations in the C-terminus. Am J Hum Genet 69:738-748

120. Kwon TH, Frokiaer J, Fernandez-Llama P, Knepper MA, Nielsen $S$ (1999) Reduced abundance of aquaporins in rats with bilateral ischemia-induced acute renal failure: prevention by alpha-MSH. Am J Physiol 277:F413-F427

121. Kwon TH, Frokiaer J, Knepper MA, Nielsen S (1998) Reduced AQP1, -2, and -3 levels in kidneys of rats with CRF induced by surgical reduction in renal mass. Am J Physiol 275:F724F741

122. Lapierre LA, Kumar R, Hales CM, Navarre J, Bhartur SG, Burnette JO, Provance DW Jr, Mercer JA, Bahler M, Goldenring JR (2001) Myosin vb is associated with plasma membrane recycling systems. Mol Biol Cell 12:1843-1857

123. Li C, Wang W, Kwon TH, Isikay L, Wen JG, Marples D, Djurhuus JC, Stockwell A, Knepper MA, Nielsen S, Frokiaer J (2001) Downregulation of AQP1, -2, and -3 after ureteral obstruction is associated with a long-term urine-concentrating defect. Am J Physiol Renal Physiol 281:F163-F171

124. Li C, Wang W, Summer SN, Cadnapaphornchai MA, Falk S, Umenishi F, Schrier RW (2006) Hyperosmolality in vivo upregulates aquaporin 2 water channel and $\mathrm{Na}-\mathrm{K}-2 \mathrm{Cl}$ cotransporter in Brattleboro rats. J Am Soc Nephrol 17:16571664

125. Li L, Schafer JA (1998) Dopamine inhibits vasopressindependent cAMP production in the rat cortical collecting duct. Am J Physiol 275:F62-F67

126. Li SZ, McDill BW, Kovach PA, Ding L, Go WY, Ho SN, Chen F (2007) Calcineurin-NFATc signaling pathway regulates AQP2 expression in response to calcium signals and osmotic stress. Am J Physiol Cell Physiol 292:C1606-C1616

127. Li Y, Shaw S, Kamsteeg EJ, Vandewalle A, Deen PM (2006) Development of lithium-induced nephrogenic diabetes insipidus is dissociated from adenylyl cyclase activity. J Am Soc Nephrol 17:1063-1072

128. Lin SH, Bichet DG, Sasaki S, Kuwahara M, Arthus MF, Lonergan M, Lin YF (2002) Two novel aquaporin-2 mutations responsible for congenital nephrogenic diabetes insipidus in Chinese families. J Clin Endocrinol Metab 87:2694-2700

129. Lloyd DJ, Hall FW, Tarantino LM, Gekakis N (2005) Diabetes insipidus in mice with a mutation in aquaporin-2. PLoS Genet 1:e20

130. Lopez-Rodriguez C, Antos CL, Shelton JM, Richardson JA, Lin F, Novobrantseva TI, Bronson RT, Igarashi P, Rao A, Olson EN (2004) Loss of NFAT5 results in renal atrophy and lack of tonicity-responsive gene expression. Proc Natl Acad Sci USA 101:2392-2397

131. Lorenz D, Krylov A, Hahm D, Hagen V, Rosenthal W, Pohl P, Maric K (2003) Cyclic AMP is sufficient for triggering the exocytic recruitment of aquaporin-2 in renal epithelial cells. EMBO Rep 4:88-93

132. Lu H, Sun TX, Bouley R, Blackburn K, McLaughlin M, Brown D (2004) Inhibition of endocytosis causes phosphorylation (S256)-independent plasma membrane accumulation of AQP2. Am J Physiol Renal Physiol 286:F233-F243

133. Lu HA, Sun TX, Matsuzaki T, Yi XH, Eswara J, Bouley R, McKee M, Brown D (2007) Heat shock protein 70 interacts with aquaporin-2 and regulates its trafficking. J Biol Chem 282:28721-28732

134. Lu W, Fan X, Basora N, Babakhanlou H, Law T, Rifai N, Harris PC, Perez-Atayde AR, Rennke HG, Zhou J (1999) Late onset of renal and hepatic cysts in Pkd1-targeted heterozygotes. Nat Genet 21:160-161

135. Lu W, Peissel B, Babakhanlou H, Pavlova A, Geng L, Fan X, Larson C, Brent G, Zhou J (1997) Perinatal lethality with kidney and pancreas defects in mice with a targetted Pkd1 mutation. Nat Genet 17:179-181

136. Maeda Y, Han JS, Gibson CC, Knepper MA (1993) Vasopressin and oxytocin receptors coupled to $\mathrm{Ca} 2$ mobilization in rat inner medullary collecting duct. Am J Physiol 265:F15-F25

137. Maeda Y, Terada Y, Nonoguchi H, Knepper MA (1992) Hormone and autacoid regulation of cAMP production in rat IMCD subsegments. Am J Physiol 263:F319-F327

138. Magenheimer BS, St John PL, Isom KS, Abrahamson DR, De Lisle RC, Wallace DP, Maser RL, Grantham JJ, Calvet JP (2006) Early embryonic renal tubules of wild-type and polycystic kidney disease kidneys respond to cAMP stimulation with cystic fibrosis transmembrane conductance regulator $/ \mathrm{Na}(), \mathrm{K}(), 2 \mathrm{Cl}(-)$ Co-transporter-dependent cystic dilation. J Am Soc Nephrol 17:3424-3437

139. Mandon B, Chou CL, Nielsen S, Knepper MA (1996) Syntaxin-4 is localized to the apical plasma membrane of rat renal collecting duct cells: possible role in aquaporin- 2 trafficking. J Clin Invest 98:906-913

140. Mandon B, Nielsen S, Kishore BK, Knepper MA (1997) Expression of syntaxins in rat kidney. Am J Physiol 42:F718-F730

141. Mangoo-Karim R, Uchic ME, Grant M, Shumate WA, Calvet JP, Park CH, Grantham JJ (1989) Renal epithelial fluid secretion and cyst growth: the role of cyclic AMP. FASEB J 3:2629-2632

142. Marples D, Christensen S, Christensen EI, Ottosen PD, Nielsen S (1995) Lithium-induced downregulation of aquaporin-2 water channel expression in rat kidney medulla. J Clin Invest 95:1838-1845

143. Marples D, Frokiaer J, Dorup J, Knepper MA, Nielsen S (1996) Hypokalemia-induced downregulation of aquaporin-2 water channel expression in rat kidney medulla and cortex. J Clin Invest 97:1960-1968

144. Marples D, Schroer TA, Ahrens N, Taylor A, Knepper MA, Nielsen S (1998) Dynein and dynactin colocalize with aqp2 water channels in intracellular vesicles from kidney collecting duct. Am J Physiol 43:F384-F394 
145. Marr N, Bichet DG, Hoefs S, Savelkoul PJ, Konings IB, De Mattia F, Graat MP, Arthus MF, Lonergan M, Fujiwara TM, Knoers NVAM, Landau D, Balfe WJ, Oksche A, Rosenthal W, Muller D, van Os CH, Deen PMT (2002) Cell-biologic and functional analyses of five new aquaporin-2 missense mutations that cause recessive nephrogenic diabetes insipidus. J Am Soc Nephrol 13:2267-2277

146. Marr N, Bichet DG, Lonergan M, Arthus MF, Jeck N, Seyberth HW, Rosenthal W, van Os CH, Oksche A, Deen PMT (2002) Heteroligomerization of an aquaporin-2 mutant with wild-type aquaporin- 2 and their misrouting to late endosomes/lysosomes explains dominant nephrogenic diabetes insipidus. Hum Mol Genet 11:779-789

147. Marr N, Kamsteeg EJ, Van Raak M, van Os CH, Deen PMT (2001) Functionality of aquaporin-2 missense mutants in recessive nephrogenic diabetes insipidus. Pflugers Arch 442:73-77

148. Masyuk AI, Masyuk TV, Splinter PL, Huang BQ, Stroope AJ, LaRusso NF (2006) Cholangiocyte cilia detect changes in luminal fluid flow and transmit them into intracellular $\mathrm{Ca} 2$ and cAMP signaling. Gastroenterology 131:911-920

149. Matsumura Y, Uchida S, Rai T, Sasaki S, Marumo F (1997) Transcriptional regulation of aquaporin-2 water channel gene by cAMP. J Am Soc Nephrol 8:861-867

150. McDill BW, Li SZ, Kovach PA, Ding L, Chen F (2006) Congenital progressive hydronephrosis (cph) is caused by an S256L mutation in aquaporin-2 that affects its phosphorylation and apical membrane accumulation. Proc Natl Acad Sci USA 103:6952-6957

151. McKinley MJ, Cairns MJ, Denton DA, Egan G, Mathai ML, Uschakov A, Wade JD, Weisinger RS, Oldfield BJ (2004) Physiological and pathophysiological influences on thirst. Physiol Behav 81:795-803

152. Mochizuki T, Wu G, Hayashi T, Xenophontos SL, Veldhuisen B, Saris JJ, Reynolds DM, Cai Y, Gabow PA, Pierides A, Kimberling WJ, Breuning MH, Deltas CC, Peters DJ, Somlo S (1996) PKD2, a gene for polycystic kidney disease that encodes an integral membrane protein. Science 272:1339-1342

153. Mulders SM, Bichet DG, Rijss JPL, Kamsteeg EJ, Arthus MF, Lonergan M, Fujiwara M, Morgan K, Leijendekker R, van der Sluijs P, van Os CH, Deen PMT (1998) An aquaporin-2 water channel mutant which causes autosomal dominant nephrogenic diabetes insipidus is retained in the Golgi complex. J Clin Invest 102:57-66

154. Mulders SM, Knoers NVAM, van Lieburg AF, Monnens LAH, Leumann E, Wuhl E, Schober E, Rijss JPL, van Os CH, Deen PMT (1997) New mutations in the AQP2 gene in nephrogenic diabetes insipidus resulting in functional but misrouted water channels. J Am Soc Nephrol 8:242-248

155. Nadler SP, Hebert SC, Brenner BM (1986) PGE2, forskolin, and cholera toxin interactions in rabbit cortical collecting tubule. Am J Physiol 250:F127-F135

156. Nadler SP, Zimpelmann JA, Hebert RL (1992) Endothelin inhibits vasopressin-stimulated water permeability in rat terminal inner medullary collecting duct. J Clin Invest 90:1458-1466

157. Nadler SP, Zimpelmann JA, Hebert RL (1992) PGE2 inhibits water permeability at a post-cAMP site in rat terminal inner medullary collecting duct. Am J Physiol 262:F229-F235

158. Nagao S, Nishii K, Katsuyama M, Kurahashi H, Marunouchi T, Takahashi H, Wallace DP (2006) Increased water intake decreases progression of polycystic kidney disease in the PCK rat. J Am Soc Nephrol 17:2220-2227

159. Nauli SM, Alenghat FJ, Luo Y, Williams E, Vassilev P, Li X, Elia AE, Lu W, Brown EM, Quinn SJ, Ingber DE, Zhou J (2003) Polycystins 1 and 2 mediate mechanosensation in the primary cilium of kidney cells. Nat Genet 33:129-137

160. Nedvetsky PI, Stefan E, Frische S, Santamaria K, Wiesner B, Valenti G, Hammer JA III, Nielsen S, Goldenring JR, Rosenthal
W, Klussmann E (2007) A role of myosin Vb and Rab11-FIP2 in the Aquaporin-2 Shuttle. Traffic 8:110-123

161. Nejsum LN, Zelenina M, Aperia A, Frokiaer J, Nielsen S (2005) Bidirectional regulation of $\mathrm{AQP} 2$ trafficking and recycling: involvement of AQP2-S256 phosphorylation. Am J Physiol Renal Physiol 288:F930-F938

162. Nielsen S, Chou CL, Marples D, Christensen EI, Kishore BK, Knepper MA (1995) Vasopressin increases water permeability of kidney collecting duct by inducing translocation of aquaporinCD water channels to plasma membrane. Proc Natl Acad Sci USA 92:1013-1017

163. Nielsen S, Digiovanni SR, Christensen EI, Knepper MA, Harris HW (1993) Cellular and subcellular immunolocalization of vasopressin-regulated water channel in rat kidney. Proc Natl Acad Sci USA 90:11663-11667

164. Nielsen S, Kwon TH, Frokiaer J, Agre P (2007) Regulation and dysregulation of aquaporins in water balance disorders. J Intern Med 261:53-64

165. Nielsen S, Marples D, Birn H, Mohtashami M, Dalby NO, Trimble W, Knepper MA (1995) Expression of VAMP2-like protein in kidney collecting duct intracellular vesicles - colocalization with aquaporin-2 water channels. J Clin Invest 96:1834-1844

166. Nielsen S, Terris J, Andersen D, Ecelbarger C, Frokiaer J, Jonassen T, Marples D, Knepper MA, Petersen JS (1997) Congestive heart failure in rats is associated with increased expression and targeting of aquaporin-2 water channel in collecting duct. Proc Natl Acad Sci USA 94:5450-5455

167. Nizet A, Lefebvre P, Crabbe J (1971) Control by insulin of sodium potassium and water excretion by the isolated dog kidney. Pflugers Arch 323:11-20

168. Noda Y, Horikawa S, Furukawa T, Hirai K, Katayama Y, Asai T, Kuwahara M, Katagiri K, Kinashi T, Hattori M, Minato N, Sasaki S (2004) Aquaporin-2 trafficking is regulated by PDZdomain containing protein SPA-1. FEBS Lett 568:139-145

169. Noda Y, Horikawa S, Katayama Y, Sasaki S (2004) Water channel aquaporin-2 directly binds to actin. Biochem Biophys Res Commun 322:740-745

170. Nonoguchi H, Owada A, Kobayashi N, Takayama M, Terada Y, Koike J, Ujiie K, Marumo F, Sakai T, Tomita K (1995) Immunohistochemical localization of V2 vasopressin receptor along the nephron and functional role of luminal V2 receptor in terminal inner medullary collecting ducts. J Clin Invest 96:1768-1778

171. Nonoguchi H, Sands JM, Knepper MA (1988) Atrial natriuretic factor inhibits vasopressin-stimulated osmotic water permeability in rat inner medullary collecting duct. J Clin Invest 82:1383-1390

172. Nonoguchi H, Sands JM, Knepper MA (1989) ANF inhibits $\mathrm{NaCl}$ and fluid absorption in cortical collecting duct of rat kidney. Am J Physiol 256:F179-F186

173. Oishi R, Nonoguchi H, Tomita K, Marumo F (1991) Endothelin-1 inhibits AVP-stimulated osmotic water permeability in rat inner medullary collecting duct. Am J Physiol 261:F951-F956

174. Oksche A, Schulein R, Rutz C, Liebenhoff U, Dickson J, Muller H, Birnbaumer M, Rosenthal W (1996) Vasopressin V2 receptor mutants that cause $\mathrm{X}$-linked nephrogenic diabetes insipidus: Analysis of expression, processing, and function. Mol Pharmacol 50:820-828

175. Pan Y, Wilson P, Gitschier J (1994) The effect of eight V2 vasopressin receptor mutations on stimulation. J Biol Chem 269:31933-31937

176. Pang L, Knox AJ (1997) PGE2 release by bradykinin in human airway smooth muscle cells: involvement of cyclooxygenase-2 induction. Am J Physiol 273:L1132-L1140

177. Parnell SC, Magenheimer BS, Maser RL, Rankin CA, Smine A, Okamoto T, Calvet JP (1998) The polycystic kidney disease-1 protein, polycystin-1, binds and activates heterotrimeric Gproteins in vitro. Biochem Biophys Res Commun 251:625-631 
178. Phillips ME, Taylor A (1989) Effect of nocodazole on the water permeability response to vasopressin in rabbit collecting tubules perfused in vitro. J Physiol (Lond) 411:529-544

179. Phillips ME, Taylor A (1992) Effect of colcemid on the water permeability response to vasopressin. J Physiol (Lond) 456:591-608

180. Prie D, Dussaule JC, Lelongt B, Geniteau-Legendre M, Chatelet F, Cassingena R, Vandewalle A, Ronco PM (1994) Principal cell-specific antigen and hormonal regulatory network in RC. SVtsA58 cell line. Am J Physiol 266:C1628-C1638

181. Procino G, Carmosino M, Tamma G, Gouraud S, Laera A, Riccardi D, Svelto M, Valenti G (2004) Extracellular calcium antagonizes forskolin-induced aquaporin 2 trafficking in collecting duct cells. Kidney Int 66:2245-2255

182. Puri S, Magenheimer BS, Maser RL, Ryan EM, Zien CA, Walker DD, Wallace DP, Hempson SJ, Calvet JP (2004) Polycystin-1 activates the calcineurin/NFAT (nuclear factor of activated T-cells) signaling pathway. J Biol Chem 279:55455-55464

183. Putnam WC, Swenson SM, Reif GA, Wallace DP, Helmkamp GM Jr, Grantham JJ (2007) Identification of a forskolin-like molecule in human renal cysts. J Am Soc Nephrol 18:934-943

184. Qian F, Germino FJ, Cai Y, Zhang X, Somlo S, Germino GG (1997) PKD1 interacts with PKD2 through a probable coiled-coil domain. Nat Genet 16:179-183

185. Raes A, Dehoorne J, Hoebeke P, Van LE, Donckerwolcke R, Vande WJ (2006) Abnormal circadian rhythm of diuresis or nocturnal polyuria in a subgroup of children with enuresis and hypercalciuria is related to increased sodium retention during daytime. J Urol 176:1147-1151

186. Ralevic V, Burnstock G (1998) Receptors for purines and pyrimidines. Pharmacol Rev 50:413-492

187. Rieg T, Schnermann J, Vallon V (2007) Adenosine A1 receptors determine effects of caffeine on total fluid intake but not caffeine appetite. Eur J Pharmacol 555:174-177

188. Robben JH, Knoers NV, Deen PM (2005) Characterization of vasopressin $\mathrm{V} 2$ receptor mutants in nephrogenic diabetes insipidus in a polarized cell model. Am J Physiol Renal Physiol 289:F265-F272

189. Robben JH, Knoers NV, Deen PM (2006) Cell biological aspects of the vasopressin type- 2 receptor and aquaporin 2 water channel in nephrogenic diabetes insipidus. Am J Physiol Renal Physiol 291:F257-F270

190. Rojek A, Fuchtbauer EM, Kwon TH, Frokiaer J, Nielsen S (2006) Severe urinary concentrating defect in renal collecting duct-selective AQP2 conditional-knockout mice. Proc Natl Acad Sci USA 103:6037-6042

191. Rosenthal W, Antaramian A, Gilbert S, Birnbaumer M (1993) Nephrogenic diabetes insipidus. A V2 vasopressin receptor unable to stimulate adenylyl cyclase. J Biol Chem 268:13030-13033

192. Rouch AJ, Chen L, Troutman SL, Schafer JA (1991) Na transport in isolated rat CCD: effects of bradykinin, ANP, clonidine, and hydrochlorothiazide. Am J Physiol 260:F86-F95

193. Sakairi Y, Jacobson HR, Noland TD, Breyer MD (1995) Luminal prostaglandin $\mathrm{E}$ receptors regulate salt and water transport in rabbit cortical collecting duct. Am J Physiol 269:F257-F265

194. Sandford R, Sgotto B, Aparicio S, Brenner S, Vaudin M, Wilson RK, Chissoe S, Pepin K, Bateman A, Chothia C, Hughes J, Harris P (1997) Comparative analysis of the polycystic kidney disease 1 (PKD1) gene reveals an integral membrane glycoprotein with multiple evolutionary conserved domains. Hum Mol Genet 6: 1483-1489

195. Sands JM, Flores FX, Kato A, Baum MA, Brown EM, Ward DT, Hebert SC, Harris HW (1998) Vasopressin-elicited water and urea permeabilities are altered in IMCD in hypercalcemic rats. Am J Physiol 274:F978-F985

196. Sands JM, Naruse M, Baum M, Jo I, Hebert SC, Brown EM, Harris HW (1997) Apical extracellular calcium/polyvalent cation-sensing receptor regulates vasopressin-elicited water permeability in rat kidney inner medullary collecting duct. J Clin Invest 99:1399-1405

197. Sauzeau V, Le JH, Cario-Toumaniantz C, Vaillant N, Gadeau AP, Desgranges C, Scalbert E, Chardin P, Pacaud P, Loirand G (2000) P2Y(1), P2Y(2), P2Y(4), and P2Y(6) receptors are coupled to Rho and Rho kinase activation in vascular myocytes. Am J Physiol Heart Circ Physiol 278:H1751-H1761

198. Schlatter E, Cermak R, Forssmann WG, Hirsch JR, Kleta R, Kuhn M, Sun D, Schafer JA (1996) cGMP-activating peptides do not regulate electrogenic electrolyte transport in principal cells of rat CCD. Am J Physiol 271:F1158-F1165

199. Schwiebert EM, Kishore BK (2001) Extracellular nucleotide signaling along the renal epithelium. Am J Physiol Renal Physiol 280:F945-F963

200. Schwiebert EM, Wallace DP, Braunstein GM, King SR, PetiPeterdi J, Hanaoka K, Guggino WB, Guay-Woodford LM, Bell PD, Sullivan LP, Grantham JJ, Taylor AL (2002) Autocrine extracellular purinergic signaling in epithelial cells derived from polycystic kidneys. Am J Physiol Renal Physiol 282:F763-F775

201. Sette C, Conti M (1996) Phosphorylation and activation of a cAMP-specific phosphodiesterase by the cAMP-dependent protein kinase. Involvement of serine 54 in the enzyme activation. J Biol Chem 271:16526-16534

202. Simon H, Gao Y, Franki N, Hays RM (1993) Vasopressin depolymerizes apical F-actin in rat inner medullary. Am J Physiol 265:C757-C762

203. Smith FD, Langeberg LK, Scott JD (2006) The where's and when's of kinase anchoring. Trends Biochem Sci 31:316-323

204. Sohara E, Rai T, Yang SS, Uchida K, Nitta K, Horita S, Ohno M, Harada A, Sasaki S, Uchida S (2006) Pathogenesis and treatment of autosomal-dominant nephrogenic diabetes insipidus caused by an aquaporin 2 mutation. Proc Natl Acad Sci USA 103:1421714222

205. Strait KA, Stricklett PK, Kohan DE (2007) Altered collecting duct adenylyl cyclase content in collecting duct endothelin-1 knockout mice. BMC Nephrol 8:8

206. Sun D, Schafer JA (1996) Dopamine inhibits AVP-dependent Na transport and water permeability in rat $\mathrm{CCD}$ via a D-4-like receptor. Am J Physiol 40:F391-F400

207. Sun R, Miller RL, Hemmert AC, Zhang P, Shi H, Nelson RD, Kishore BK (2005) Chronic dDAVP infusion in rats decreases the expression of $\mathrm{P} 2 \mathrm{Y} 2$ receptor in inner medulla and $\mathrm{P} 2 \mathrm{Y} 2$ receptormediated PGE2 release by IMCD. Am J Physiol Renal Physiol 289: F768-F776

208. Sun TX, van Hoek A, Huang Y, Bouley R, McLaughlin M, Brown D (2002) Aquaporin-2 localization in clathrin-coated pits: inhibition of endocytosis by dominant-negative dynamin. Am J Physiol Renal Physiol 282:F998-F1011

209. Takeda S, Lin CT, Morgano PG, McIntyre SJ, Dousa TP (1991) High activity of low-Michaelis-Menten constant $3 \phi, 5 \phi$-cyclic adenosine monophosphate-phosphodiesterase isozymes in renal inner medulla of mice with hereditary nephrogenic diabetes insipidus. Endocrinology 129:287-294

210. Tamarappoo BK, Verkman AS (1998) Defective aquaporin-2 trafficking in nephrogenic diabetes insipidus and correction by chemical chaperones. J Clin Invest 101:2257-2267

211. Tamma G, Carmosino M, Svelto M, Valenti G (2005) Bradykinin signaling counteracts cAMP-elicited aquaporin 2 translocation in renal cells. J Am Soc Nephrol 16:2881-2889

212. Tamma G, Klussmann E, Maric K, Aktories K, Svelto M, Rosenthal W, Valenti G (2001) Rho inhibits cAMP-induced translocation of aquaporin-2 into the apical membrane of renal cells. Am J Physiol Renal Physiol 281:F1092-F1101

213. Tamma G, Klussmann E, Oehlke J, Krause E, Rosenthal W, Svelto M, Valenti G (2005) Actin remodeling requires ERM function to facilitate AQP2 apical targeting. J Cell Sci 118:3623-3630 
214. Tamma G, Klussmann E, Procino G, Svelto M, Rosenthal W, Valenti G (2003) cAMP-induced AQP2 translocation is associated with RhoA inhibition through RhoA phosphorylation and interaction with RhoGDI. J Cell Sci 116:1519-1525

215. Tamma G, Wiesner B, Furkert J, Hahm D, Oksche A, Schaefer M, Valenti G, Rosenthal W, Klussmann E (2003) The prostaglandin E2 analogue sulprostone antagonizes vasopressininduced antidiuresis through activation of Rho. J Cell Sci 116:3285-3294

216. Teitelbaum I, McGuinness S (1995) Vasopressin resistance in chronic renal failure. Evidence for the role of decreased V2 receptor mRNA. J Clin Invest 96:378-385

217. Tomita K, Nonoguchi H, Terada Y, Marumo F (1993) Effects of ET-1 on water and chloride transport in cortical collecting ducts of the rat. Am J Physiol 264:F690-F696

218. Torres VE, Harris PC (2007) Polycystic kidney disease: genes, proteins, animal models, disease mechanisms and therapeutic opportunities. J Intern Med 261:17-31

219. Torres VE, Wang X, Qian Q, Somlo S, Harris PC, Gattone VH (2004) Effective treatment of an orthologous model of autosomal dominant polycystic kidney disease. Nat Med 10:363-364

220. Tsiokas L, Kim E, Arnould T, Sukhatme VP, Walz G (1997) Homo- and heterodimeric interactions between the gene products of PKD1 and PKD2. Proc Natl Acad Sci USA 94:6965-6970

221. Turner CM, King BF, Srai KS, Unwin RJ (2007) Antagonism of endogenous putative $\mathrm{P} 2 \mathrm{Y}$ receptors reduces the growth of MDCK-derived cysts cultured in vitro. Am J Physiol Renal Physiol 292:F15-F25

222. Turner CM, Ramesh B, Srai SK, Burnstock G, Unwin RJ (2004) Altered ATP-sensitive P2 receptor subtype expression in the Han:SPRD cy/ rat, a model of autosomal dominant polycystic kidney disease. Cells Tissues Organs 178:168-179

223. Umenishi F, Narikiyo T, Vandewalle A, Schrier RW (2006) cAMP regulates vasopressin-induced AQP2 expression via protein kinase A-independent pathway. Biochim Biophys Acta 1758:1100-1105

224. Unwin RJ, Bailey MA, Burnstock G (2003) Purinergic signaling along the renal tubule: the current state of play. News Physiol Sci 18:237-241

225. Valenti G, Laera A, Gouraud S, Pace G, Aceto G, Penza R, Selvaggi FP, Svelto M (2002) Low-calcium diet in hypercalciuric enuretic children restores AQP2 excretion and improves clinical symptoms. Am J Physiol Renal Physiol 283:F895-F903

226. Valenti G, Laera A, Pace G, Aceto G, Lospalluti ML, Penza R, Selvaggi FP, Chiozza ML, Svelto M (2000) Urinary aquaporin 2 and calciuria correlate with the severity of enuresis in children. J Am Soc Nephrol 11:1873-1881

227. Valenti G, Procino G, Carmosino M, Frigeri A, Mannucci R, Nicoletti I, Svelto M (2000) The phosphatase inhibitor okadaic acid induces AQP2 translocation independently from AQP2 phosphorylation in renal collecting duct cells. J Cell Sci 113:1985-1992

228. Van Balkom BWM, Savelkoul PJ, markovich D, Hofman E, Nielsen S, van der Sluijs P, Deen PMT (2002) The role of putative phosphorylation sites in the targeting and shuttling of the aquaporin-2 water channel. J Biol Chem 277:41473-41479

229. Verbalis JG (2007) How does the brain sense osmolality? J Am Soc Nephrol 18:3056-3059

230. Wang S, Zhang J, Nauli SM, Li X, Starremans PG, Luo Y, Roberts KA, Zhou J (2007) Fibrocystin/polyductin, found in the same protein complex with polycystin-2, regulates calcium responses in kidney epithelia. Mol Cell Biol 27:3241-3252

231. Wang W, Li C, Nejsum LN, Li H, Kim SW, Kwon TH, Jonassen TE, Knepper MA, Thomsen K, Frokiaer J, Nielsen S (2006) Biphasic effects of ANP infusion in conscious, euvolumic rats: roles of AQP2 and ENaC trafficking. Am J Physiol Renal Physiol 290:F530-F541

232. Wang X, Gattone V, Harris PC, Torres VE (2005) Effectiveness of vasopressin V2 receptor antagonists OPC-31260 and OPC41061 on polycystic kidney disease development in the PCK rat. J Am Soc Nephrol 16:846-851

233. Ward CJ, Hogan MC, Rossetti S, Walker D, Sneddon T, Wang X, Kubly V, Cunningham JM, Bacallao R, Ishibashi M, Milliner DS, Torres VE, Harris PC (2002) The gene mutated in autosomal recessive polycystic kidney disease encodes a large, receptor-like protein. Nat Genet 30:259-269

234. Ward CJ, Yuan D, Masyuk TV, Wang X, Punyashthiti R, Whelan $\mathrm{S}$, Bacallao R, Torra R, LaRusso NF, Torres VE, Harris PC (2003) Cellular and subcellular localization of the ARPKD protein; fibrocystin is expressed on primary cilia. Hum Mol Genet 12:2703-2710

235. Welch BD, Carlson NG, Shi H, Myatt L, Kishore BK (2003) P2Y2 receptor-stimulated release of prostaglandin E2 by rat inner medullary collecting duct preparations. Am J Physiol Renal Physiol 285:F711-F721

236. Wenkert D, Schoneberg T, Merendino JJ, Pena MSR, Vinitsky R, Goldsmith PK, Wess J, Spiegel AM (1996) Functional characterization of five V2 vasopressin receptor gene mutations. Mol Cell Endocrinol 124:43-50

237. Wu Y, Dai XQ, Li Q, Chen CX, Mai W, Hussain Z, Long W, Montalbetti N, Li G, Glynne R, Wang S, Cantiello HF, Wu G, Chen XZ (2006) Kinesin-2 mediates physical and functional interactions between polycystin-2 and fibrocystin. Hum Mol Genet 15:3280-3292

238. Xiong H, Chen Y, Yi Y, Tsuchiya K, Moeckel G, Cheung J, Liang D, Tham K, Xu X, Chen XZ, Pei Y, Zhao ZJ, Wu G (2002) A novel gene encoding a TIG multiple domain protein is a positional candidate for autosomal recessive polycystic kidney disease. Genomics 80:96-104

239. Xu DL, Martin PY, Ohara M, Stjohn J, Pattison T, Meng XZ, Morris K, Kim JK, Schrier RW (1997) Upregulation of aquaporin-2 water channel expression in chronic heart failure rat. J Clin Invest 99:1500-1505

240. Yamaguchi T, Hempson SJ, Reif GA, Hedge AM, Wallace DP (2006) Calcium restores a normal proliferation phenotype in human polycystic kidney disease epithelial cells. J Am Soc Nephrol 17:178-187

241. Yamaguchi T, Pelling JC, Ramaswamy NT, Eppler JW, Wallace DP, Nagao S, Rome LA, Sullivan LP, Grantham JJ (2000) cAMP stimulates the in vitro proliferation of renal cyst epithelial cells by activating the extracellular signal-regulated kinase pathway. Kidney Int 57:1460-1471

242. Yamaguchi T, Wallace DP, Magenheimer BS, Hempson SJ, Grantham JJ, Calvet JP (2004) Calcium restriction allows cAMP activation of the B-Raf/ERK pathway, switching cells to a cAMP-dependent growth-stimulated phenotype. J Biol Chem 279:40419-40430

243. Yamaki M, McIntyre S, Rassier ME, Schwartz JH, Dousa TP (1992) Cyclic 3\&,5ф-nucleotide diesterases in dynamics of cAMP and cGMP in rat collecting duct cells. Am J Physiol 262: F957-F964

244. Yang B, Gillespie A, Carlson EJ, Epstein CJ, Verkman AS (2000) Neonatal mortality in an aquaporin-2 knock-in mouse model of recessive nephrogenic diabetes insipidus. J Biol Chem 276:2775-2779

245. Yang B, Zhao D, Qian L, Verkman AS (2006) Mouse model of inducible nephrogenic diabetes insipidus produced by floxed aquaporin-2 gene deletion. Am J Physiol Renal Physiol 291: F465-F472

246. Yasui M, Zelenin SM, Celsi G, Aperia A (1997) Adenylate cyclase-coupled vasopressin receptor activates $\mathrm{AQP} 2$ promoter 
via a dual effect on CRE and AP1 elements. Am J Physiol 41: F443-F450

247. Yip KP (2002) Coupling of vasopressin-induced intracellular Ca (2) mobilization and apical exocytosis in perfused rat kidney collecting duct. J Physiol 538:891-899

248. Yip KP (2006) Epac mediated Ca2 mobilization and exocytosis in inner medullary collecting duct. Am J Physiol Renal Physiol 291:F882-F890
249. Yoder BK, Hou X, Guay-Woodford LM (2002) The polycystic kidney disease proteins, polycystin-1, polycystin-2, polaris, and cystin, are co-localized in renal cilia. J Am Soc Nephrol 13: 2508-2516

250. Zelenina M, Christensen BM, Palmer J, Nairn AC, Nielsen S, Aperia A (2000) Prostaglandin E(2) interaction with AVP: effects on AQP2 phosphorylation and distribution. Am J Physiol Renal Physiol 278:F388-F394 